\title{
Manure and Fertilizer Inputs to Land in the Chesapeake Bay Watershed, 1950-2012
}

Scientific Investigations Report $2018-5022$

U.S. Departinent of the interior

U.S. Geological Survey 
Cover: Soybean farm in northern Maryland, August 15, 2014. Photograph by Alex Demas, U.S. Geological Survey. 


\section{Manure and Fertilizer Inputs to Land in the Chesapeake Bay Watershed, 1950-2012}

By Jennifer L.D. Keisman, Olivia H. Devereux, Andrew E. LaMotte, Andrew J.

Sekellick, and Joel D. Blomquist

Scientific Investigations Report 2018-5022 


\title{
U.S. Department of the Interior \\ RYAN K. ZINKE, Secretary
}

\author{
U.S. Geological Survey \\ James F. Reilly II, Director
}

U.S. Geological Survey, Reston, Virginia: 2018

For more information on the USGS - the Federal source for science about the Earth, its natural and living resources, natural hazards, and the environment-visit https://www.usgs.gov or call 1-888-ASK-USGS.

For an overview of USGS information products, including maps, imagery, and publications,

visit https://store.usgs.gov.

Any use of trade, firm, or product names is for descriptive purposes only and does not imply endorsement by the U.S. Government.

Although this information product, for the most part, is in the public domain, it also may contain copyrighted materials as noted in the text. Permission to reproduce copyrighted items must be secured from the copyright owner.

Suggested citation:

Keisman, J.L.D., Devereux, O.H., LaMotte, A.E., Sekellick, A.J., and Blomquist, J.D., 2018, Manure and fertilizer inputs to land in the Chesapeake Bay watershed, 1950-2012: U.S. Geological Survey Scientific Investigations Report 2018-5022, 37 p., https://doi.org/10.3133/sir20185022.

ISSN 2328-0328 (online)

ISSN 2328-031X (print) 


\section{Contents}

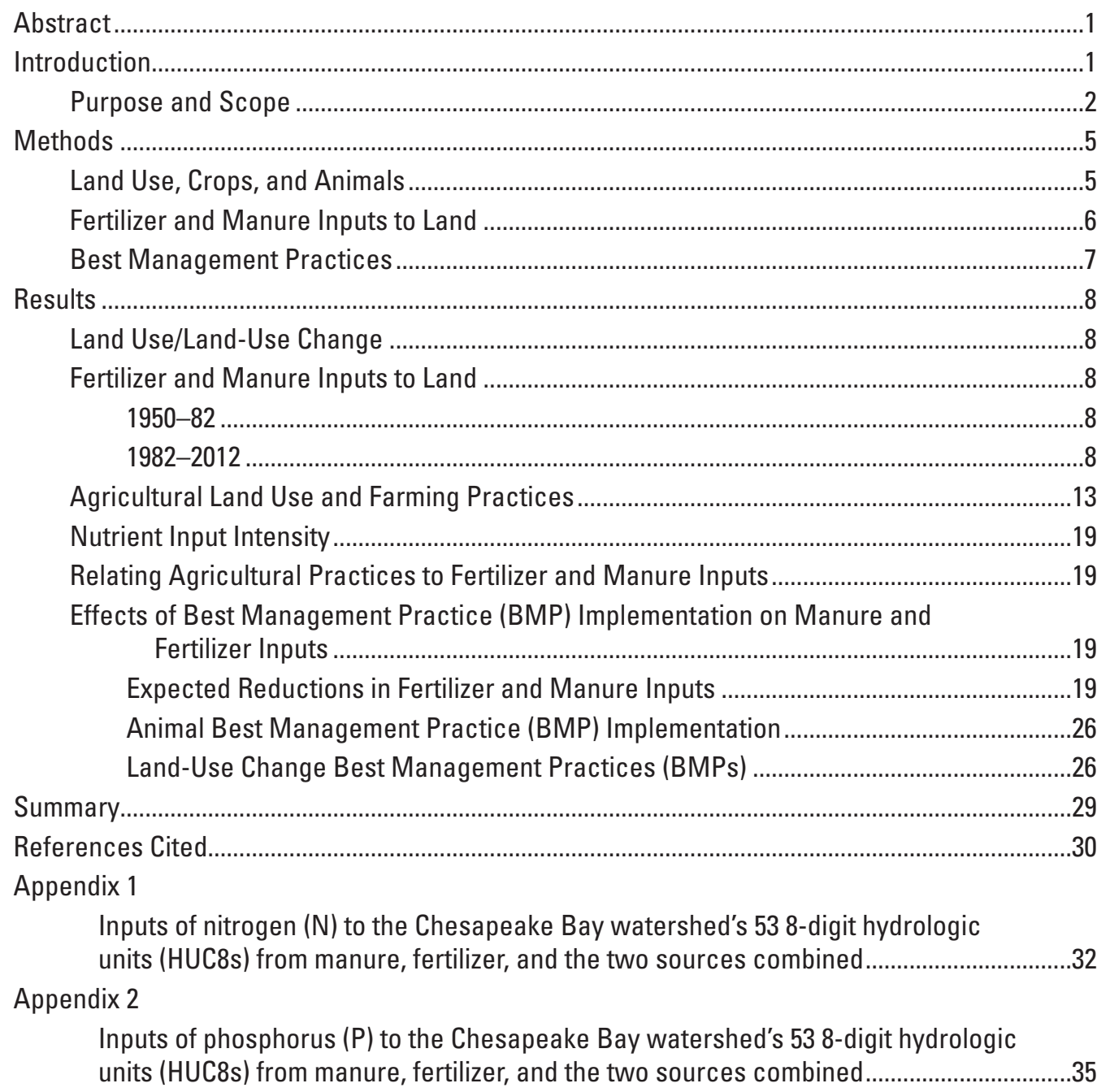




\section{Figures}

1. Map showing location of the Chesapeake Bay watershed, with 8-digit hydrologic units (HUC8s) and aggregated regions identified

2. Graph showing phasing in of reduction credit for poultry phytase implementation, 1997-2002

3. Graph showing reported implementation of agricultural land-use change best management practices (BMPs) for major regions of the Chesapeake Bay watershed, 1985-2012

4. Graphs showing $A$, nitrogen, and $B$, phosphorus inputs to the Chesapeake Bay watershed from manure and fertilizer, 1950-2012.

5. Boxplots showing range and variability of the change in agricultural $A$, nitrogen inputs, and $B$, phosphorus inputs from 1950-82 and 1982-2012 in the Chesapeake Bay watershed at the 8-digit hydrologic unit (HUC8) scale ....

6. Graphs showing change in agricultural $A$, nitrogen inputs, and $B$, phosphorus inputs for each 8-digit hydrologic basin (HUC8) in the Chesapeake Bay watershed from 1982 to 2012

7. Graphs showing spatial variability of $A$, major crop groups, and $B$, major animal groups in the Chesapeake Bay watershed in 1982 and 2012

8. Maps showing input intensity of $A$, nitrogen $(\mathrm{N})$ and $B$, phosphorus $(\mathrm{P})$ on agricultural acres in the Chesapeake Bay watershed in 1982.

9. Maps showing input intensity change from 1982 to 2012 for $A$, nitrogen (N) and $B$, phosphorus $(\mathrm{P})$ in the Chesapeake Bay watershed

10. Graphs showing nitrogen fertilizer use on harvested cropland by proportion of cropland devoted to $A$, grain corn, and $B$, silage corn in the Chesapeake Bay watershed.

11. Graphs showing expected effect of best management practices (BMPs) on $A$, nitrogen (N) and $B$, phosphorus (P) applications to land in the Chesapeake Bay watershed, 1985-2012.

12. Graphs showing $A$, expected percent change in manure-phosphorus (manure-P) applications due to best management practices (BMPs) from 1985 to 2012 (dark blue bars), and B, 2012 poultry populations (light blue bars) in the Chesapeake Bay watershed

13. Graph showing reported implementation of agricultural land-use change best management practices (BMPs) for major regions of the Chesapeake Bay watershed, 1985-2012

14. Map showing implementation of agricultural land-use change best management practices (BMPs) as of 2012 (percent of eligible acres) in the Chesapeake Bay watershed. 


\section{Tables}

1. 8-Digit hydrologic units (HUC8s) of the Chesapeake Bay watershed, grouped

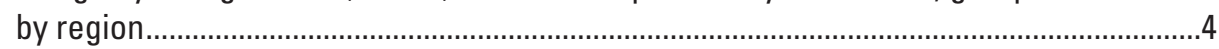

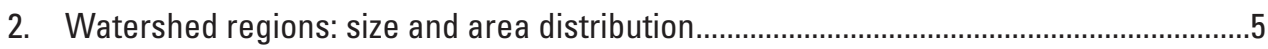

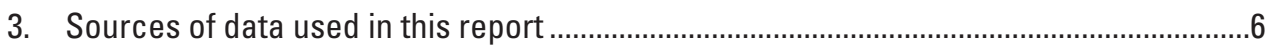

4. Animal number to animal unit (AU) conversion assumptions used by the Chesapeake Bay Program, and revised assumptions used and described in the Methods section of this report...........................................................................6

5. Percent of land area in each land-use class in the Chesapeake Bay watershed,

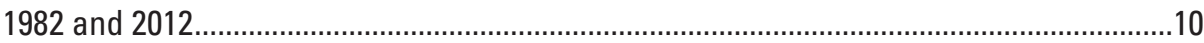

6. Changes over time in agricultural nitrogen $(N)$ and phosphorus $(P)$ inputs to seven distinct regions of the watershed, 1950-2012 …..................................................11

7. Changes in farmland area (acres) in the Chesapeake Bay watershed,

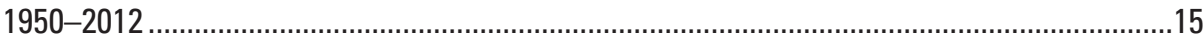

8. Changes in spatial variability of harvested cropland in the Chesapeake Bay watershed in 1950, 1982, and 2012.

9. Percentage of acres harvested for six dominant crop types in the Chesapeake

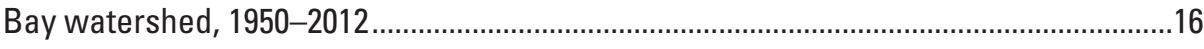

10. Annual percentage of animal biomass (in animal units) for the five major animal types produced in the Chesapeake Bay watershed, 1950-2012.

11. Intensity of agricultural nutrient inputs to seven major regions in the Chesapeake Bay watershed in 1950, 1982, and 2012.

12. Expected change in nitrogen $(\mathrm{N})$ and phosphorus $(\mathrm{P})$ applications in the Chesapeake Bay watershed with and without best management practice (BMP) implementation, 1985-2012

13. Spatial variability in expected changes in manure and fertilizer inputs due to best management practice (BMP) implementation in the Chesapeake Bay watershed, 1985-2012.

14. Dairy precision feeding implementation rates in the Chesapeake Bay watershed, 2007-12. 


\section{Conversion Factors}

Inch/Pound to International System of Units

\begin{tabular}{lcl}
\hline \multicolumn{1}{c}{ Multiply } & By & \multicolumn{1}{c}{ To obtain } \\
\hline foot $(\mathrm{ft})$ & Length & meter $(\mathrm{m})$ \\
\hline & 0.3048 & \\
\hline acre & Area & square kilometer $\left(\mathrm{km}^{2}\right)$ \\
square mile $\left(\mathrm{mi}^{2}\right)$ & 0.004047 & hectare $($ ha) \\
square mile $\left(\mathrm{mi}^{2}\right)$ & 259.0 & square kilometer $\left(\mathrm{km}^{2}\right)$ \\
\hline & 2.590 & \\
\hline pound, avoirdupois $(\mathrm{lb})$ & Mass & kilogram $(\mathrm{kg})$ \\
\hline
\end{tabular}

Temperature in degrees Celsius $\left({ }^{\circ} \mathrm{C}\right)$ may be converted to degrees Fahrenheit $\left({ }^{\circ} \mathrm{F}\right)$ as follows:

$$
{ }^{\circ} \mathrm{F}=\left(1.8 \times{ }^{\circ} \mathrm{C}\right)+32 .
$$

Temperature in degrees Fahrenheit $\left({ }^{\circ} \mathrm{F}\right)$ may be converted to degrees Celsius $\left({ }^{\circ} \mathrm{C}\right)$ as follows:

$$
{ }^{\circ} \mathrm{C}=\left({ }^{\circ} \mathrm{F}-32\right) / 1.8 .
$$

Horizontal coordinate information is referenced to the North American Datum of 1983 (NAD83). 


\section{Abbreviations}

$\begin{array}{ll}\text { AU } & \text { Animal unit } \\ \text { BMP } & \text { Best management practice } \\ \text { CBP } & \text { Chesapeake Bay Program } \\ \text { CBPO } & \text { EPA Chesapeake Bay Program Office } \\ \text { COA } & \text { Census of Agriculture } \\ \text { EPA } & \text { U.S. Environmental Protection Agency } \\ \text { HUC } & \text { Hydrologic unit code } \\ \text { HUC8 } & \text { 8-digit hydrologic unit } \\ \text { N } & \text { Total Nitrogen } \\ \text { NAWQA } & \text { USGS National Water-Quality Assessment Project } \\ \text { NWALT } & \text { National Water-Quality Assessment Wall-to-Wall Anthropogenic Land-Use } \\ \text { P } & \text { Trends } \\ \text { TMDL } & \text { Total Phosphorus } \\ \text { USDA } & \text { Total Maximum Daily Load } \\ \text { USGS } & \text { U.S. Department of Agriculture }\end{array}$





\title{
Manure and Fertilizer Inputs to Land in the Chesapeake Bay Watershed, 1950-2012
}

\author{
By Jennifer L.D. Keisman¹, Olivia H. Devereux², Andrew E. LaMotte ${ }^{1}$, Andrew J. Sekellick', and \\ Joel D. Blomquist ${ }^{1}$
}

\section{Abstract}

Understanding changing nutrient concentrations in surface waters requires quantitative information on changing nutrient sources in contributing watersheds. For example, the proportion of nutrient inputs reaching streams and rivers is directly affected by when and where those nutrients enter the landscape. The goal of this report is to contribute to the U.S. Geological Survey's efforts to describe spatial and temporal patterns in nutrient inputs to the landscape in the Chesapeake Bay watershed, thereby informing efforts to understand changes in riverine and estuarine conditions. The magnitude, spatial variability, and changes over time in nutrient inputs from manure and fertilizer were evaluated in the context of changes in land use and agricultural practices from 1950 through 2012 at three spatial scales: the entire Chesapeake Bay watershed, the 53 8-digit hydrologic units (HUC8s) that are contained within the watershed, and a set of 7 regions that were determined by aggregating geographically similar HUC8s. The expected effect of agricultural best management practices (BMPs) on agricultural nutrient inputs from 1985 through 2012 was also investigated. Nitrogen (N) and phosphorus $(\mathrm{P})$ inputs from manure increased gradually over time at the scale of the entire watershed. Fertilizer-N inputs showed steeper increases, with greater inter-annual fluctuations. Fertilizer-P inputs were less variable, increasing moderately from 1950 through the mid-1970s, and declining thereafter. Nutrient inputs and farming practices varied geographically within the watershed, with implications for the potential impact of these inputs on downstream water quality and ecosystem health. Both temporal and spatial patterns in the intensity of agricultural nutrient inputs were consistent with the magnitude and concentration of livestock and poultry populations and the intensity of row crop agriculture. Reported implementation of the animal and land-use change BMPs that were evaluated were expected to have little effect on agricultural $\mathrm{N}$ inputs. Animal BMPs were expected to have a more measurable impact on manure-P inputs, particularly in areas with large poultry populations. Understanding these patterns is

\footnotetext{
${ }^{1}$ U.S. Geological Survey.

${ }^{2}$ Devereux Consulting, Inc.
}

important for explaining the changes that have been observed in nutrient loads to the rivers and streams of the Chesapeake Bay watershed, and their impacts on the water quality and ecosystem health of Chesapeake Bay itself.

\section{Introduction}

The Chesapeake Bay watershed covers about 64,000 square miles $\left(\mathrm{mi}^{2}\right)$, stretching across seven jurisdictions made up of six states (Delaware, Maryland, New York, Pennsylvania, Virginia, and West Virginia) as well as Washington, D.C. The watershed drains into an estuary covering a surface area of about $4,400 \mathrm{mi}^{2}$, with a mean depth of about 21.3 feet (ft) (Kemp and others, 2005). Pressures such as increasing population, agricultural production, and urban development across the watershed have degraded water quality and living resources in the Chesapeake Bay, leading to the establishment of a Total Maximum Daily Load (TMDL) regulating the amount of nitrogen, phosphorus, and sediment that jurisdictions may discharge into the watershed's rivers, streams, and tidal waters (U.S. Environmental Protection Agency, 2010). In order to comply with the Chesapeake Bay TMDL, jurisdictions are implementing best management practices (BMPs) designed to reduce the amount of nitrogen, phosphorus, and sediment draining to tidal waters.

Nitrogen $(\mathrm{N})$ and phosphorus $(\mathrm{P})$ inputs from agriculture (for example, manure and inorganic fertilizer combined) currently constitute the largest source of nutrient inputs to the landscape in the Chesapeake Bay watershed (Boesch and others, 2001; U.S. Environmental Protection Agency, 2010a), as well as the predominant source of nutrients delivered to Chesapeake Bay (Ator and others, 2011). Manure inputs can occur in feed lots, manure storage structures, or pasture, or can be applied to cropland as fertilizer, while inorganic fertilizer is generally applied to cropland. Understanding the absolute magnitude and spatial variability of manure and inorganic fertilizer inputs can inform further analysis of the relative impact of nutrient loads to Chesapeake Bay from different regions; a pound of $\mathrm{N}$ or $\mathrm{P}$ applied to land in the far western edge of the watershed does not have the same impact on Chesapeake Bay's water quality as a pound applied to land closer to the 
Bay's shoreline (Linker and others, 2013). Variable landscape conditions including soil erodibility, soil drainage properties, physiographic region, and rainfall patterns also lead to the variable contributions from uplands to streams and the Bay (Ator and Garcia, 2016). Understanding how the amount and location of manure and fertilizer inputs have changed over time may help managers understand the causes of improving or degrading water quality across the watershed, thereby informing their decisions regarding the future level of implementation and placement of BMPs.

\section{Purpose and Scope}

The purpose of this report is to document the magnitude of $\mathrm{N}$ and $\mathrm{P}$ inputs to land from manure and inorganic fertilizer from 1950 through 2012 in the Chesapeake Bay watershed, and to describe changes in spatial variability over time. Inputs from other sources, such as biosolids from wastewater treatment plants that may be spread on fields in agricultural areas, are not considered in this report. Land-use change is explored - as are temporal and spatial patterns in agricultural land use and farming practices contributing to manure and fertilizer inputs - in order to better understand observed patterns in manure and fertilizer inputs. Both the amount of past implementation (1985-2012) and the expected effects of BMPs that directly affect manure and fertilizer inputs are also described. The term "expected effects" refers to the effects of BMPs as estimated from modeling scenarios provided by the Chesapeake Bay Program (CBP). The actual effects of these BMPs on nutrient inputs from manure and fertilizer may not yet be fully realized.

Inputs of $\mathrm{N}$ and $\mathrm{P}$ from manure and fertilizer are presented for the Chesapeake Bay watershed as a whole, and at the subbasin, or 8-digit, scale of the Watershed Boundary Dataset (U.S. Geological Survey and U.S. Department of Agriculture, Natural Resources Conservation Service, 2013). These subbasins were delineated using science-based hydrologic principles and assigned unique hydrologic unit codes (HUCs). There are a total of 53 8-digit scale hydrologic units (HUC8s) in the Chesapeake Bay watershed (fig. 1; table 1). HUC8s are also aggregated to seven categories corresponding to key regions of interest within the watershed (table 2). Changes in $\mathrm{N}$ and $\mathrm{P}$ inputs are compared with changes in agricultural land-use practices, such as the cultivation of crops and animal populations, and with the reporting of certain agricultural BMPs between 1985 and 2012. 


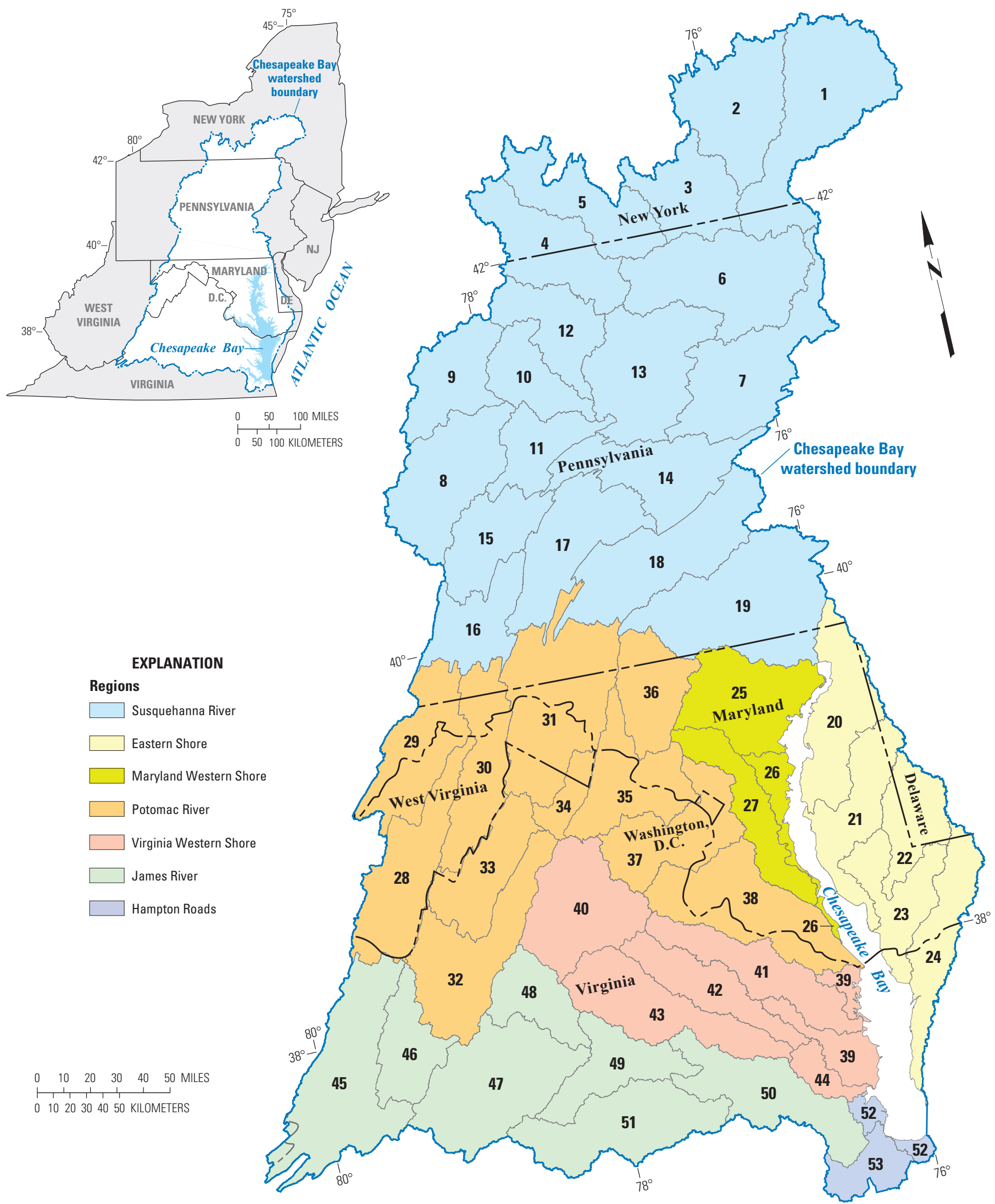

Figure 1. Location of the Chesapeake Bay watershed, with 8-digit hydrologic units (HUC8s) and aggregated regions identified. [Integers shown for each HUC8 correspond to those listed in table 1.] 
Table 1. 8-Digit hydrologic units (HUC8s) of the Chesapeake Bay watershed, grouped by region. The column labeled "HUC8 number" corresponds to those on the map of the Chesapeake Bay watershed shown in figure 1; the column labeled "8-digit code" contains the U.S. Geological Survey 8-digit identifier for each HUC8.

\begin{tabular}{|c|c|c|c|c|}
\hline Region & HUC8 name & HUC8 number & 8-digit code & $\begin{array}{c}\text { Area } \\
\text { (square miles) }\end{array}$ \\
\hline \multirow{19}{*}{ Susquehanna } & Upper Susquehanna & 1 & 02050101 & 2,287 \\
\hline & Chenango & 2 & 02050102 & 1,606 \\
\hline & Owego-Wappasening & 3 & 02050103 & 1,044 \\
\hline & Tioga & 4 & 02050104 & 1,382 \\
\hline & Chemung & 5 & 02050105 & 1,210 \\
\hline & Upper Susquehanna-Tunkhannock & 6 & 02050106 & 2,004 \\
\hline & Upper Susquehanna-Lackawanna & 7 & 02050107 & 1,766 \\
\hline & Upper West Branch Susquehanna & 8 & 02050201 & 1,597 \\
\hline & Sinnemahoning & 9 & 02050202 & 1,034 \\
\hline & Middle West Branch Susquehanna & 10 & 02050203 & 784 \\
\hline & Bald Eagle & 11 & 02050204 & 773 \\
\hline & Pine & 12 & 02050205 & 981 \\
\hline & Lower West Branch Susquehanna & 13 & 02050206 & 1,810 \\
\hline & Lower Susquehanna-Penns & 14 & 02050301 & 1,448 \\
\hline & Upper Juniata & 15 & 02050302 & 991 \\
\hline & Raystown & 16 & 02050303 & 962 \\
\hline & Lower Juniata & 17 & 02050304 & 1,450 \\
\hline & Lower Susquehanna-Swatara & 18 & 02050305 & 1,876 \\
\hline & Lower Susquehanna & 19 & 02050306 & 2,482 \\
\hline \multirow{5}{*}{ Eastern Shore } & Chester-Sassafras & 20 & 02060002 & 1,083 \\
\hline & Choptank & 21 & 02060005 & 801 \\
\hline & Nanticoke & 22 & 02080109 & 791 \\
\hline & Tangier & 23 & 02080110 & 651 \\
\hline & Pocomoke-Western Lower Delmarva & 24 & 02080111 & 842 \\
\hline \multirow{3}{*}{$\begin{array}{c}\text { Maryland } \\
\text { Western Shore }\end{array}$} & Gunpowder-Patapsco & 25 & 02060003 & 1,303 \\
\hline & Severn & 26 & 02060004 & 294 \\
\hline & Patuxent & 27 & 02060006 & 879 \\
\hline \multirow{11}{*}{ Potomac } & South Branch Potomac & 28 & 02070001 & 1,480 \\
\hline & North Branch Potomac & 29 & 02070002 & 1,343 \\
\hline & Cacapon-Town & 30 & 02070003 & 1,205 \\
\hline & Conococheague-Opequon & 31 & 02070004 & 2,277 \\
\hline & South Fork Shenandoah & 32 & 02070005 & 1,672 \\
\hline & North Fork Shenandoah & 33 & 02070006 & 1,034 \\
\hline & Shenandoah & 34 & 02070007 & 352 \\
\hline & Middle Potomac-Catoctin & 35 & 02070008 & 1,237 \\
\hline & Monocacy & 36 & 02070009 & 970 \\
\hline & Middle Potomac-Anacostia-Occoquan & 37 & 02070010 & 1,255 \\
\hline & Lower Potomac & 38 & 02070011 & 1,350 \\
\hline
\end{tabular}


Table 1. 8-Digit hydrologic units (HUC8s) of the Chesapeake Bay watershed, grouped by region. The column labeled "HUC8 number" corresponds to those on the map of the Chesapeake Bay watershed shown in figure 1; the column labeled "8-digit code" contains the U.S. Geological Survey 8-digit identifier for each HUC8. - Continued

\begin{tabular}{|c|c|c|c|c|}
\hline Region & HUC8 name & HUC8 number & 8-digit code & $\begin{array}{c}\text { Area } \\
\text { (square miles) }\end{array}$ \\
\hline \multirow{3}{*}{$\begin{array}{c}\text { Virginia } \\
\text { Western Shore }\end{array}$} & Great Wicomico-Piankatank & 39 & 02080102 & 516 \\
\hline & Lower Rappahannock & 41 & 02080104 & 1,002 \\
\hline & Mattaponi & 42 & 02080105 & 904 \\
\hline \multirow[b]{4}{*}{ James } & Upper James & 45 & 02080201 & 2,211 \\
\hline & Maury & 46 & 02080202 & 838 \\
\hline & Middle James-Buffalo & 47 & 02080203 & 2,023 \\
\hline & Rivanna & 48 & 02080204 & 768 \\
\hline \multirow{2}{*}{ Hampton Roads } & Lynnhaven-Poquoson & 52 & 02080108 & 176 \\
\hline & Hampton Roads & 53 & 02080208 & 401 \\
\hline
\end{tabular}

Table 2. Watershed regions: size and area distribution.

[HUC8, 8-digit hydrologic unit]

\begin{tabular}{ccccc}
\hline Region & Number of HUC8s & Acres & Square miles & Percent of total \\
\hline Susquehanna & 19 & $17,591,020$ & 27,486 & 43 \\
Eastern Shore & 5 & $2,667,233$ & 4,168 & 6 \\
Maryland Western Shore & 3 & $1,585,094$ & 2,477 & 4 \\
\hline Potomac & 11 & $9,070,399$ & 14,173 & 92 \\
Virginia Western Shore & 6 & $3,621,594$ & 5,659 & 15 \\
\hline James & 7 & $6,169,892$ & 9,640 & 577 \\
\hline Hampton Roads & 2 & 369,345 & $\mathbf{6 4 , 1 8 0}$ & $\mathbf{1 0 0}$ \\
\hline
\end{tabular}

\section{Methods}

Data on land use, farmland area and use, cultivated crop types, livestock and poultry numbers, and manure and fertilizer inputs were combined to investigate changing spatial patterns over time in agricultural nutrient inputs and factors affecting those inputs (table 3). Patterns were explored at three spatial scales - the Chesapeake Bay watershed, HUC8, and seven regions of interest - and for 2 time periods: the entire period of record (1950-2012) and the most recent 30 years of record (1982-2012). Sizes and locations of HUC8s were obtained from the Watershed Boundary Dataset (WBD), a nationally standardized collection of hydrologic unit data developed and maintained cooperatively by the U.S. Department of Agriculture (USDA), the U.S.
Geological Survey (USGS), and the Environmental Protection Agency (EPA). Data on reported BMP implementation for the years 1985-2012, along with the results of modeling scenarios described below, were used to explore the expected effects of BMP implementation on nutrient inputs to the watershed for each year from 1985 to 2012 .

\section{Land Use, Crops, and Animals}

Changes in land use from 1982 to 2012 were described based on the USGS National Water-Quality Assessment Wallto-Wall Anthropogenic Land-Use Trends (NWALT) dataset (Falcone, 2015). NWALT land use classes were aggregated to four major categories as follows: "developed" and "semideveloped" classes were combined into one "developed" 
Table 3. Sources of data used in this report.

\begin{tabular}{llc}
\hline \multicolumn{1}{c}{ Data } & \multicolumn{1}{c}{ Source } & Time period \\
\hline Fertilizer use & Sekellick, 2017 & 1-year increments 1950-2012 \\
Manure production & Sekellick, 2017 & 5 -year increments 1950-2012 \\
Crop acres and yields; animal populations & LaMotte, 2015 & 5 -year increments 1950-2012 \\
\hline Land use, land-use change & Falcone, 2015 & $1974,1982,1987,1992,2012$ \\
Best management practice implementation & Devereux and others, 2017 & 1-year increments 1985-2012 \\
\hline
\end{tabular}

category; "low use" and "very low use, conservation" classes were combined into one "natural" category; the "crops" and "pasture/hay" production subclasses were combined into an "agriculture" category; and the "wetlands," "mining/extraction," and "grazing potential" production subclasses were combined into an "other" category. The proportion of land in each of these four categories was evaluated at both the watershed scale and the HUC8 scales. To further explore changes in agricultural land use and agricultural practices, data from the USDA Census of Agriculture (COA) were used to quantify changes in the amount of cropland and pasture, in crops cultivated, and in animal populations (LaMotte, 2015). The COA reports data at the county scale. To facilitate analysis at the HUC8 scale, COA data were re-allocated from county to HUC8s by distributing the animal inventory equally across the agricultural pixels of a county, and then summing by HUC8. This assumed that animals were co-located with cropland and pasture.

Certain crop types tend to be co-located with livestock and (or) poultry populations, which may have implications for both manure and commercial fertilizer usage (Beegle, 2013). To illustrate this pattern for the Chesapeake Bay watershed, crop data from the COA were grouped into the following categories: forage (hay, alfalfa, and silage hay), silage corn, grain corn, and soybeans. To compare livestock and poultry populations with crop types, animals were grouped into cows (beef, dairy, other), hogs, and poultry (layers, pullets, broilers, and turkeys).

In order to evaluate the relative contribution of each animal to total animal biomass in the watershed, the head counts for five animal types (cows, poultry, horses, sheep, and hogs) were converted to animal units (AUs) using methods developed by the CBP Partnership (table 4) (Chesapeake Bay Program, 2013), with some modifications to accommodate differences between the animal categories used by the CBP and those used in the USGS dataset. For example, the average of the CBP's animal unit conversion assumptions for layers and pullets was used to estimate chicken AUs in the USGS dataset.

\section{Fertilizer and Manure Inputs to Land}

Changes in manure and fertilizer- $\mathrm{N}$ and - $\mathrm{P}$ inputs as well as in $\mathrm{N}$ and $\mathrm{P}$ input intensity (a measure of nutrient input per acre of cropland) were compared within and among the
Table 4. Animal number to animal unit (AU) conversion assumptions used by the Chesapeake Bay Program (Chesapeake Bay Program, 2013), and revised assumptions used and described in the Methods section of this report.

[CBP, Chesapeake Bay Program; USGS, U.S. Geological Survey; N/A, not applicable]

\begin{tabular}{lcc}
\hline \multicolumn{1}{c}{ Animal type } & $\begin{array}{c}\text { Animals per AU, } \\
\text { CBP }\end{array}$ & $\begin{array}{c}\text { Animals per AU, } \\
\text { USGS }\end{array}$ \\
\hline Broilers & 455 & 455 \\
Layers & 250 & N/A \\
Pullets & 352.5 & N/A \\
\hline Chickens & N/A & 301.25 \\
Turkeys & 67 & 67 \\
Angora goats & 15.38 & N/A \\
Milk goats & 15.38 & N/A \\
Beef & 1.14 & 1.14 \\
Dairy & 0.74 & 0.74 \\
\hline Other cattle & 2.08 & 2.08 \\
\hline Hogs and pigs for breeding & 2.67 & 2.67 \\
\hline Hogs for slaughter & 9.09 & N/A \\
\hline Horses & 1 & 1 \\
\hline Sheep and lambs & 10 & 10 \\
\hline
\end{tabular}

53 HUC8s and seven regions. Data on fertilizer and manure inputs to the Chesapeake Bay watershed were obtained from Sekellick (2017). Historical crop, agricultural land-use, livestock, and poultry data were derived from the USDA COA for the Census Years from 1950 through 2012. These data are a subset of the data presented in LaMotte (2015). The NWALT dataset was used to derive areas that were defined as agricultural. NWALT consists of five land-use rasters covering the years 1974, 1982, 1992, 2002, and 2012. Agricultural pixels were defined based on NWALT second-level classes 43 (crops), 44 (pasture/hay), and 45 (grazing potential). Crop pixels were defined by NWALT second-level class 43 (crops). County-level census input estimates were evenly distributed across agricultural or crop pixels for each county by dividing the county total by the number of thematic pixels. Pixels (and their associated agricultural census values) were then summed for each 8-digit HUC and each of the seven distinct regions in the Chesapeake Bay watershed. Examining changes at both 
the HUC8 scale and the regional scale provided an additional layer of information on geographic shifts in nutrients within the watershed.

Temporal and spatial patterns in the magnitude of manure and inorganic fertilizer inputs to the Chesapeake Bay watershed were evaluated for 1950-2012. At finer geographic scales within the watershed, changes in manure and fertilizer inputs between 1982 and 2012 were evaluated in order to coincide (approximately) with the 1985-2012 period for which the CBP had evaluated nutrient inputs and BMP implementation. Changes in input amounts during 1992, 2002, and 2012 for $\mathrm{N}$ (Appendix 1) and for $\mathrm{P}$ (Appendix 2) were compiled as supplementary material to support further analysis to explain observed changes in water quality. Linear regression was performed in R3.3.2 (R Core Team, 2016) to explore relations between fertilizer usage and the cultivation of different crop types across the watershed.

\section{Best Management Practices}

Data on the reported implementation of BMPs were retrieved from the Chesapeake Bay Program Office (CBPO) databases in July 2016 (Chesapeake Bay Program, 2013). These datasets were collected for use as inputs to the Phase 5.3.2 version of the CBP's Chesapeake Bay Watershed Model (U.S. Environmental Protection Agency, 2010). The Chesapeake Bay jurisdictions report the BMP data to the $\mathrm{CBPO}$ annually. The spatial scale varies depending on the BMP, state preference, and year. Some BMPs are reported at very specific scales, such as county, whereas others are reported at the HUC4 scale. The CBPO disaggregates the BMP data to the CBP Phase 5.3.2 Watershed Model land-river segments. BMPs were further assigned to HUC8s according to the HUC8 in which most of the land-river segment's area was located. Both the spatial and temporal distribution in BMP implementation from 1985 (the first year for which these data are available) to 2012, as well as their expected effects, were quantified. The resulting dataset includes the BMP name, the amount of that BMP implemented, land-use or animal type, and HUC8 to which the implementation was assigned.

To estimate the expected effect of BMP implementation on changes in $\mathrm{N}$ and $\mathrm{P}$ over time, output from the CBP Phase 5.3.2 Scenario Builder (Chesapeake Bay Program, 2013) was also obtained from the CBPO and allocated to the HUC8 scale. Output consisted of the results of a set of "No Action" and "Progress" scenarios run for each year between 1985 and 2012. No Action scenarios produced manure and fertilizer input datasets consistent with real-world estimates, based on the assumption that no BMPs were in place in each given year. In the Progress scenarios, manure and fertilizer input datasets were modified by applying assumptions of the effect of reported BMPs, based on the expectation that all BMPs reported by and credited to the jurisdictions were in place and functioning.
Only the animal and agricultural land-use change BMPs that affect nutrient inputs to land were included in this analysis. There are three animal BMPs tracked by the states that reduce $\mathrm{N}$ and (or) $\mathrm{P}$ inputs to the land by reducing the nutrient concentration in animals' manure: changes in feed for poultry and swine, and dairy precision feeding and (or) forage management. Feed changes for poultry and swine include phytase, an enzyme added to animal feed to increase the amount of $\mathrm{P}$ that can be absorbed into the animal's biomass. This increased efficiency of $\mathrm{P}$ absorption enables manufacturers to add less $\mathrm{P}$ to the feed, and also reduces the P content of manure (Chesapeake Bay Program, 2015). The intensity and effect of swine phytase implementation was not evaluated because implementation was not reported by the major jurisdictions until after 2012. Another animal BMP - manure transport - also affects local manure inputs. Manure can be transported from the location in which it was generated by the animal, to another location to be applied to the land. This is commonly done in areas that have a high number of animals and little row cropland. Manure may be transported among farms and out of the watershed.

For purposes of estimating the effect of poultry phytase implementation on manure-P inputs to the land, the CBP gradually increased the calculated benefit of phytase implementation over a 5-year period from 1997 through 2002 as follows: benefits were assumed to begin for all poultry as of 1997, and the full effect of that implementation (indicated by a reduction in P content of manure) was gradually phased in between 1997 and 2002. The credited reduction in the P content of poultry manure due to phytase implementation was increased from 4 percent to 21 percent for broilers and turkeys, and from 3 percent to 16 percent for layers and pullets (fig. 2).

The agricultural land-use change BMPs described in this report eliminate the manure and fertilizer applied to cropland, hay, and pasture land uses by converting these lands to agricultural land uses that do not receive manure or fertilizer, and (or) to natural land uses like forest or wetlands, thereby eliminating manure and fertilizer input to these areas. Landuse changes over time for reasons other than BMP implementation are excluded; thus, the intensity and expected effects

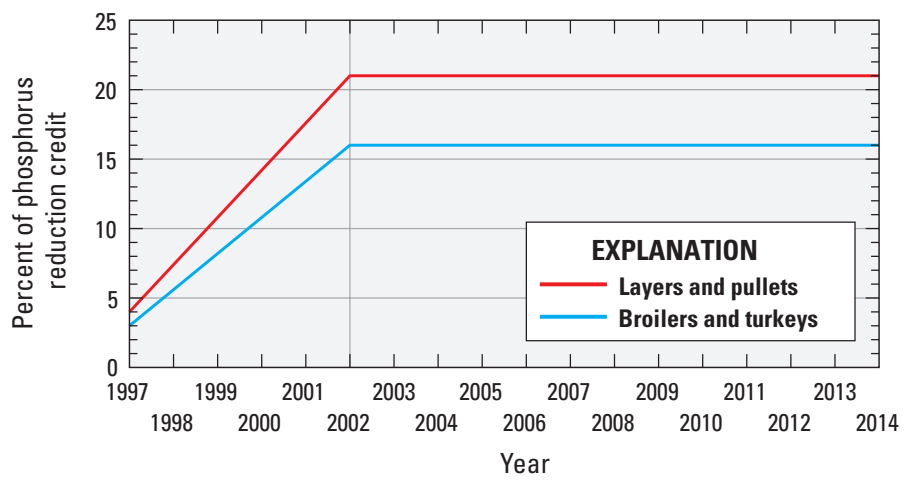

Figure 2. Phasing in of reduction credit for poultry phytase implementation, 1997-2002. 
of BMP implementation described are distinguished from the effects of other changes in land use such as urban development or re-forestation. The total amount of BMP acres in a HUC8 can exceed the total agricultural area because more than one type of BMP can occur on the same acre of land.

\section{Results}

\section{Land Use/Land-Use Change}

In 1982, 58 percent of the watershed was considered to be in a "natural" condition (parks and other areas showed no evidence of regular human usage; Falcone, 2015), with the remainder divided between agriculture (28 percent), urban development (11 percent), or other uses ( 3 percent). About 6 percent of the watershed's total area was developed between 1982 and 2012 (about 4 percent from natural areas and 2 percent from agriculture). Overall, developed land area increased by about 49 percent - from about 4.58 million acres to about 6.83 million acres - between 1982 and 2012.

Consistent with the pattern at the watershed scale, most Chesapeake HUC8s were dominated by natural areas in both 1982 and 2012 (fig. 3; table 5). However, eight HUC8s ${ }^{3}$ contained a greater proportion of land in agriculture than in any other use in 1982, and six HUC8s $\mathrm{s}^{4}$ contained more area in developed than in either the natural, agricultural, or other land-use categories.

All 53 HUC8s experienced some degree of urbanization between 1982 and 2012; in most of these cases urbanization occurred through the development of both agricultural and natural lands. However, the proportion of land in agriculture was unchanged or had increased slightly (less than 0.5 percent) in three ${ }^{5} \mathrm{HUC} 8 \mathrm{~s}$ by 2012 . In these cases, development of natural areas accounted for urbanization. Natural land area was unchanged or increased (up to 2 percent) in five HUC $8 \mathrm{~s}^{6}$. In these cases, urbanization occurred through development of agricultural areas.

By 2012, a total of 13 HUC8s contained more developed land than agricultural land. These HUC8s were categorized as "predominantly urban" in order to reflect the differential impact that development had on their manure and fertilizer input patterns.

\footnotetext{
${ }^{3}$ Chester-Sassafras, Choptank, Lower Susquehanna, Middle PotomacCatoctin, Monocacy, Nanticoke, Shenandoah, Tangier.

${ }^{4}$ Gunpowder-Patapsco, Hampton Roads, Lynnhaven-Poquoson, Middle Potomac-Anacostia-Occoquan, Patuxent, Severn.

${ }^{5}$ North Branch Potomac, Sinnemahoning, Upper West Branch Susquehanna.

${ }^{6}$ Chenango, Nanticoke, Pine, Tioga, Upper Susquehanna.
}

\section{Fertilizer and Manure Inputs to Land}

$\mathrm{N}$ inputs to land in the Chesapeake Bay watershed from manure and inorganic fertilizer combined increased by over 90 percent between 1950 and 1982, and peaked at about 960 million pounds in 2000 before decreasing to 812 million pounds in 2012. Increases over time in $\mathrm{P}$ inputs were less dramatic (about 13 percent) between 1950 and 1982, but $P$ inputs decreased by about 26 percent between 1982 and 2012 .

Temporal shifts in agricultural $\mathrm{N}$ and $\mathrm{P}$ inputs were largely driven by changing patterns in inorganic fertilizer use (fig. 4). Fertilizer-N inputs increased sharply from 1950-71, after which they declined by 14 million pounds from 1971 to 2012, but with inter-annual fluctuations of as much as 117 million pounds. Fertilizer-P inputs increased by about 27 million pounds from 1950 to 1971 and then declined by about 106 million pounds, with inter-annual fluctuations of as much as 27 million pounds. Estimates of manure inputs were derived directly from livestock and poultry populations (Sekellick, 2017), and it was assumed that manure remained where it was produced (the potential impact of manure transport is discussed later in this report). Based on this assumption, manure inputs increased moderately and gradually over time, in concert with animal populations.

The greater variability observed in fertilizer inputs reflects a more complex matrix of drivers, such as crop type, acreage, and projected yields, as well as fertilizer prices, weather, and manure availability (Stuart and others, 2015).

\section{$1950-82$}

$\mathrm{N}$ inputs from agriculture increased from 1950 to 1982 in 50 out of the 53 HUC8s throughout the watershed (not shown), and in all regions of the watershed in general (table 6). P inputs increased in $25 \mathrm{HUC} 8 \mathrm{~s}$, and in 4 out of 7 regions, with the greatest percent increase occurring in the Eastern Shore region. The largest percent decrease was seen in the Hampton Roads (Virginia) region, reflecting the highly urban nature of the Lynnhaven-Poquoson and Hampton Roads HUC8s.

\section{2-2012}

In contrast to the prior period, $25 \mathrm{HUC} 8 \mathrm{~s}$ (about half) experienced increasing agricultural $\mathrm{N}$ inputs from 1982 to 2012, with a narrower distribution and a median change close to zero (fig 5). Only seven HUC8s had increased P inputs; changes ranged from a decrease of 7.9 million pounds to an increase of 1.2 million pounds.

Reductions in both $\mathrm{N}$ and $\mathrm{P}$ inputs resulted primarily from a decline in fertilizer use (fig. 6); inputs of $\mathrm{N}$ and $\mathrm{P}$ from manure increased over this period in almost half of the HUC8s studied. The changes in the spatial distribution of inputs 


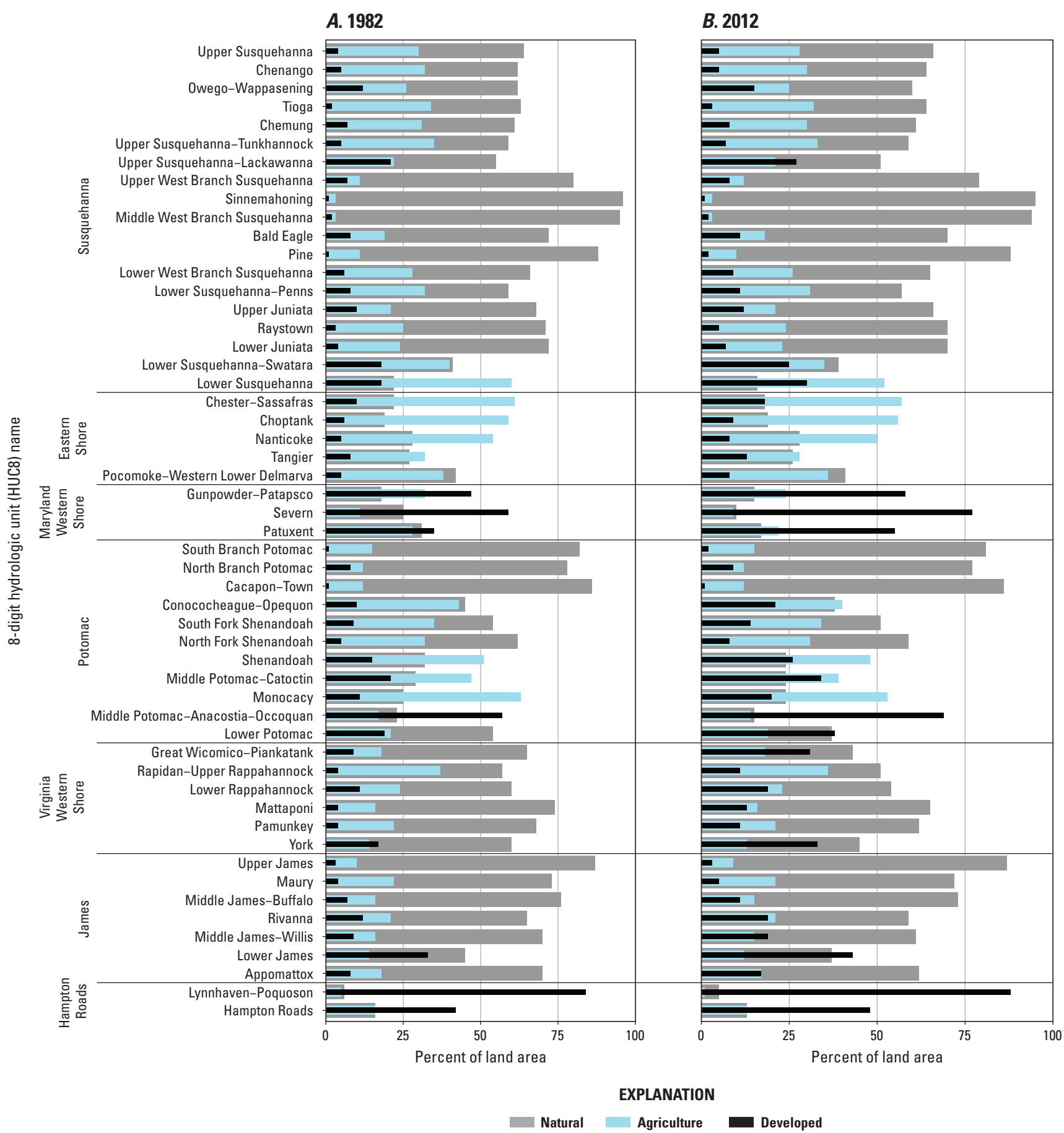

Figure 3. Reported implementation of agricultural land-use change best management practices (BMPs) for major regions of the Chesapeake Bay watershed, 1985-2012. [Bars represent accumulated implementation as of a given year; the black line represents the percent of the total (as of 2012) BMP implementation for all regions.] 
Table 5. Percent of land area in each land-use class in the Chesapeake Bay watershed, 1982 and 2012.

[HUC8, 8-digit hydrologic unit]

\begin{tabular}{|c|c|c|c|c|c|c|c|c|c|}
\hline \multirow[t]{2}{*}{ Region } & \multirow[t]{2}{*}{ HUC8 name } & \multicolumn{2}{|c|}{$\begin{array}{c}\text { Natural } \\
\text { (percent) }\end{array}$} & \multicolumn{2}{|c|}{$\begin{array}{c}\text { Developed } \\
\text { (percent) }\end{array}$} & \multicolumn{2}{|c|}{$\begin{array}{c}\text { Agriculture } \\
\text { (percent) }\end{array}$} & \multicolumn{2}{|c|}{$\begin{array}{c}\text { Other } \\
\text { (percent) }\end{array}$} \\
\hline & & 1982 & 2012 & 1982 & 2012 & 1982 & 2012 & 1982 & 2012 \\
\hline \multirow{14}{*}{ Susquehanna } & Upper Susquehanna & 64 & 66 & 4 & 5 & 30 & 28 & 1 & 1 \\
\hline & Chenango & 62 & 64 & 5 & 5 & 32 & 30 & 1 & 1 \\
\hline & Owego-Wappasening & 62 & 60 & 12 & 15 & 26 & 25 & 0 & 0 \\
\hline & Upper Susquehanna-Tunkhannock & 59 & 59 & 5 & 7 & 35 & 33 & 1 & 1 \\
\hline & Upper Susquehanna-Lackawanna & 55 & 51 & 21 & 27 & 22 & 21 & 1 & 1 \\
\hline & Upper West Branch Susquehanna & 80 & 79 & 7 & 8 & 11 & 12 & 2 & 2 \\
\hline & Sinnemahoning & 96 & 95 & 1 & 1 & 3 & 3 & 0 & 0 \\
\hline & Lower West Branch Susquehanna & 66 & 65 & 6 & 9 & 28 & 26 & 0 & 0 \\
\hline & Lower Susquehanna-Penns & 59 & 57 & 8 & 11 & 32 & 31 & 1 & 1 \\
\hline & Upper Juniata & 68 & 66 & 10 & 12 & 21 & 21 & 1 & 1 \\
\hline & Raystown & 71 & 70 & 3 & 5 & 25 & 24 & 1 & 1 \\
\hline & Lower Juniata & 72 & 70 & 4 & 7 & 24 & 23 & 1 & 0 \\
\hline & Lower Susquehanna-Swatara & 41 & 39 & 18 & 25 & 40 & 35 & 1 & 1 \\
\hline & Lower Susquehanna & 22 & 16 & 18 & 30 & 60 & 52 & 1 & 1 \\
\hline \multirow{2}{*}{ Eastern Shore } & Chester-Sassafras & 22 & 18 & 10 & 18 & 61 & 57 & 7 & 7 \\
\hline & Choptank & 19 & 19 & 6 & 9 & 59 & 56 & 16 & 16 \\
\hline \multirow{11}{*}{ Potomac } & South Branch Potomac & 82 & 81 & 1 & 2 & 15 & 15 & 1 & 1 \\
\hline & North Branch Potomac & 78 & 77 & 8 & 9 & 12 & 12 & 2 & 2 \\
\hline & Cacapon-Town & 86 & 86 & 1 & 1 & 12 & 12 & 1 & 1 \\
\hline & Conococheague-Opequon & 45 & 38 & 10 & 21 & 43 & 40 & 1 & 1 \\
\hline & South Fork Shenandoah & 54 & 51 & 9 & 14 & 35 & 34 & 1 & 1 \\
\hline & North Fork Shenandoah & 62 & 59 & 5 & 8 & 32 & 31 & 2 & 1 \\
\hline & Shenandoah & 32 & 24 & 15 & 26 & 51 & 48 & 2 & 2 \\
\hline & Middle Potomac-Catoctin & 29 & 24 & 21 & 34 & 47 & 39 & 3 & 3 \\
\hline & Monocacy & 25 & 24 & 11 & 20 & 63 & 53 & 2 & 3 \\
\hline & Middle Potomac-Anacostia-Occoquan & 23 & 15 & 57 & 69 & 17 & 14 & 2 & 2 \\
\hline & Lower Potomac & 54 & 37 & 19 & 38 & 21 & 19 & 6 & 6 \\
\hline
\end{tabular}


Table 5. Percent of land area in each land-use class in the Chesapeake Bay watershed, 1982 and 2012.—Continued

[HUC8, 8-digit hydrologic unit]

\begin{tabular}{|c|c|c|c|c|c|c|c|c|c|}
\hline \multirow[t]{2}{*}{ Region } & \multirow[t]{2}{*}{ HUC8 name } & \multicolumn{2}{|c|}{$\begin{array}{c}\text { Natural } \\
\text { (percent) }\end{array}$} & \multicolumn{2}{|c|}{$\begin{array}{c}\text { Developed } \\
\text { (percent) }\end{array}$} & \multicolumn{2}{|c|}{$\begin{array}{c}\text { Agriculture } \\
\text { (percent) }\end{array}$} & \multicolumn{2}{|c|}{$\begin{array}{c}\text { Other } \\
\text { (percent) }\end{array}$} \\
\hline & & 1982 & 2012 & 1982 & 2012 & 1982 & 2012 & 1982 & 2012 \\
\hline \multirow{4}{*}{$\begin{array}{c}\text { Virginia } \\
\text { Western Shore }\end{array}$} & Great Wicomico-Piankatank & 65 & 43 & 9 & 31 & 18 & 18 & 8 & 8 \\
\hline & Rapidan-Upper Rappahannock & 57 & 51 & 4 & 11 & 37 & 36 & 2 & 2 \\
\hline & Lower Rappahannock & 60 & 54 & 11 & 19 & 24 & 23 & 5 & 5 \\
\hline & York & 60 & 45 & 17 & 33 & 14 & 13 & 9 & 9 \\
\hline \multirow{4}{*}{ James } & Upper James & 87 & 87 & 3 & 3 & 10 & 9 & 1 & 1 \\
\hline & Maury & 73 & 72 & 4 & 5 & 22 & 21 & 2 & 2 \\
\hline & Middle James-Buffalo & 76 & 73 & 7 & 11 & 16 & 15 & 1 & 1 \\
\hline & Appomattox & 70 & 62 & 8 & 17 & 18 & 17 & 4 & 4 \\
\hline \multirow{2}{*}{ Hampton Roads } & Lynnhaven-Poquoson & 6 & 5 & 84 & 88 & 5 & 1 & 5 & 5 \\
\hline & Hampton Roads & 16 & 13 & 42 & 48 & 16 & 13 & 25 & 26 \\
\hline
\end{tabular}

Table 6. Changes over time in agricultural nitrogen $(N)$ and phosphorus $(P)$ inputs to seven distinct regions of the watershed, 1950-2012 (regions are defined in table 2).

\begin{tabular}{|c|c|c|c|c|c|c|c|c|c|c|}
\hline \multirow[t]{2}{*}{ Region } & \multicolumn{3}{|c|}{$\begin{array}{c}\text { N Input } \\
\text { (million pounds) }\end{array}$} & \multicolumn{2}{|c|}{$\begin{array}{l}\text { N-Input change, } \\
\text { in percent }\end{array}$} & \multicolumn{3}{|c|}{$\begin{array}{c}\text { P Input } \\
\text { (million pounds) }\end{array}$} & \multicolumn{2}{|c|}{$\begin{array}{l}\text { P-Input change, } \\
\text { in percent }\end{array}$} \\
\hline & 1950 & 1982 & 2012 & $1950-82$ & 1982-2012 & 1950 & 1982 & 2012 & $1950-82$ & 1982-2012 \\
\hline Susquehanna & 201 & 350 & 321 & 74 & -8 & 91 & 100 & 70 & 10 & -30 \\
\hline Eastern Shore & 34 & 135 & 144 & 296 & 6 & 24 & 38 & 31 & 60 & -19 \\
\hline $\begin{array}{c}\text { Maryland Western } \\
\text { Shore }\end{array}$ & 19 & 27 & 22 & 42 & -19 & 7.8 & 7.3 & 5.6 & -6 & -23 \\
\hline Potomac & 116 & 212 & 198 & 82 & -7 & 54 & 60 & 48 & 12 & -20 \\
\hline $\begin{array}{c}\text { Virginia Western } \\
\text { Shore }\end{array}$ & 36 & 68 & 58 & 88 & -14 & 21 & 20 & 11 & -5 & -45 \\
\hline Hampton Roads & 1.8 & 3.8 & 7.1 & 114 & 89 & 1.4 & 1.2 & 1.2 & -19 & 6 \\
\hline Total & 449 & 863 & 812 & 92 & -6 & 218 & 247 & 182 & 13 & -26 \\
\hline
\end{tabular}



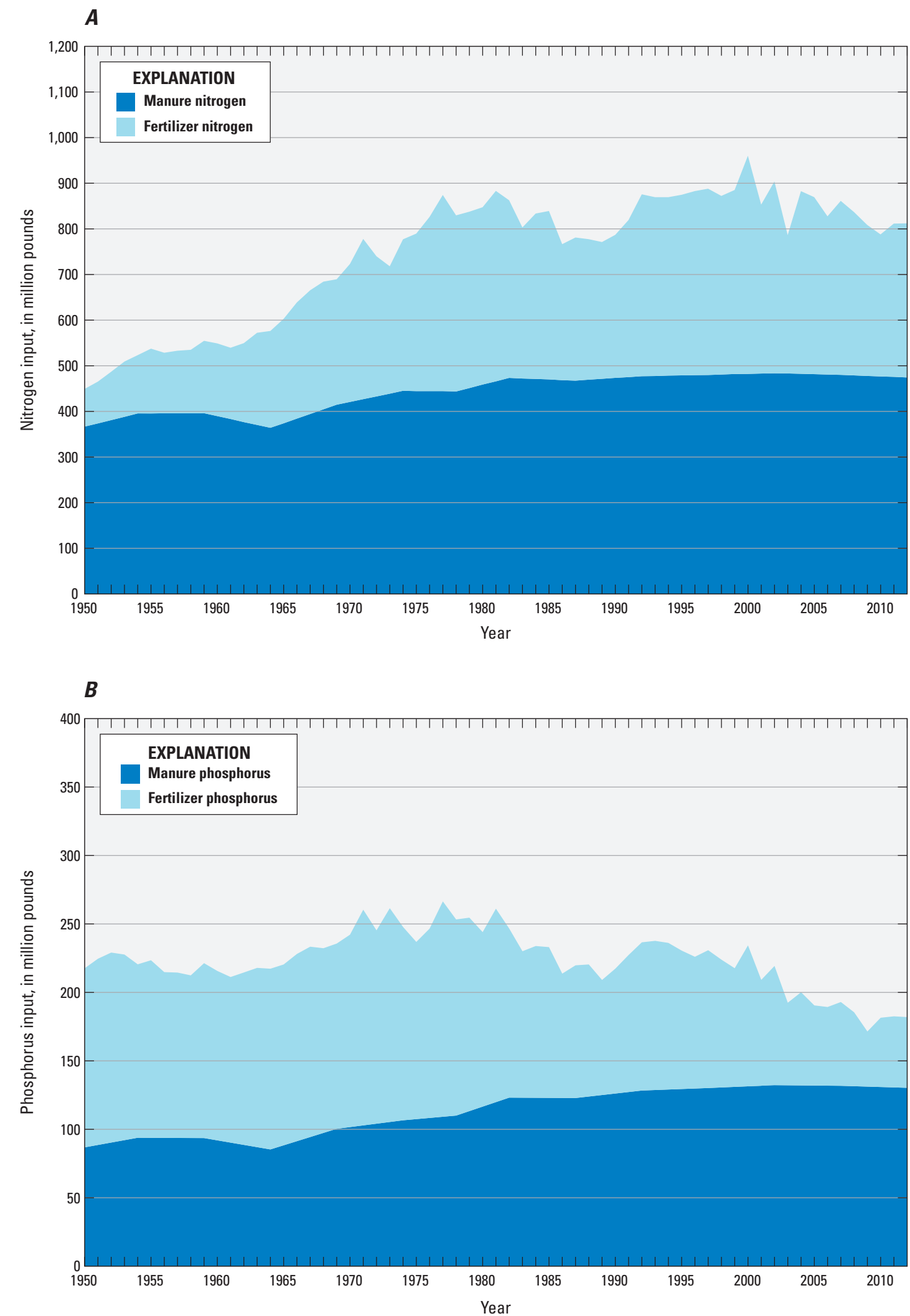

Figure 4. $A$, nitrogen, and $B$, phosphorus inputs to the Chesapeake Bay watershed from manure and fertilizer, 1950-2012. [Note difference in scales of $y$ axes.] 
$\boldsymbol{A}$

B

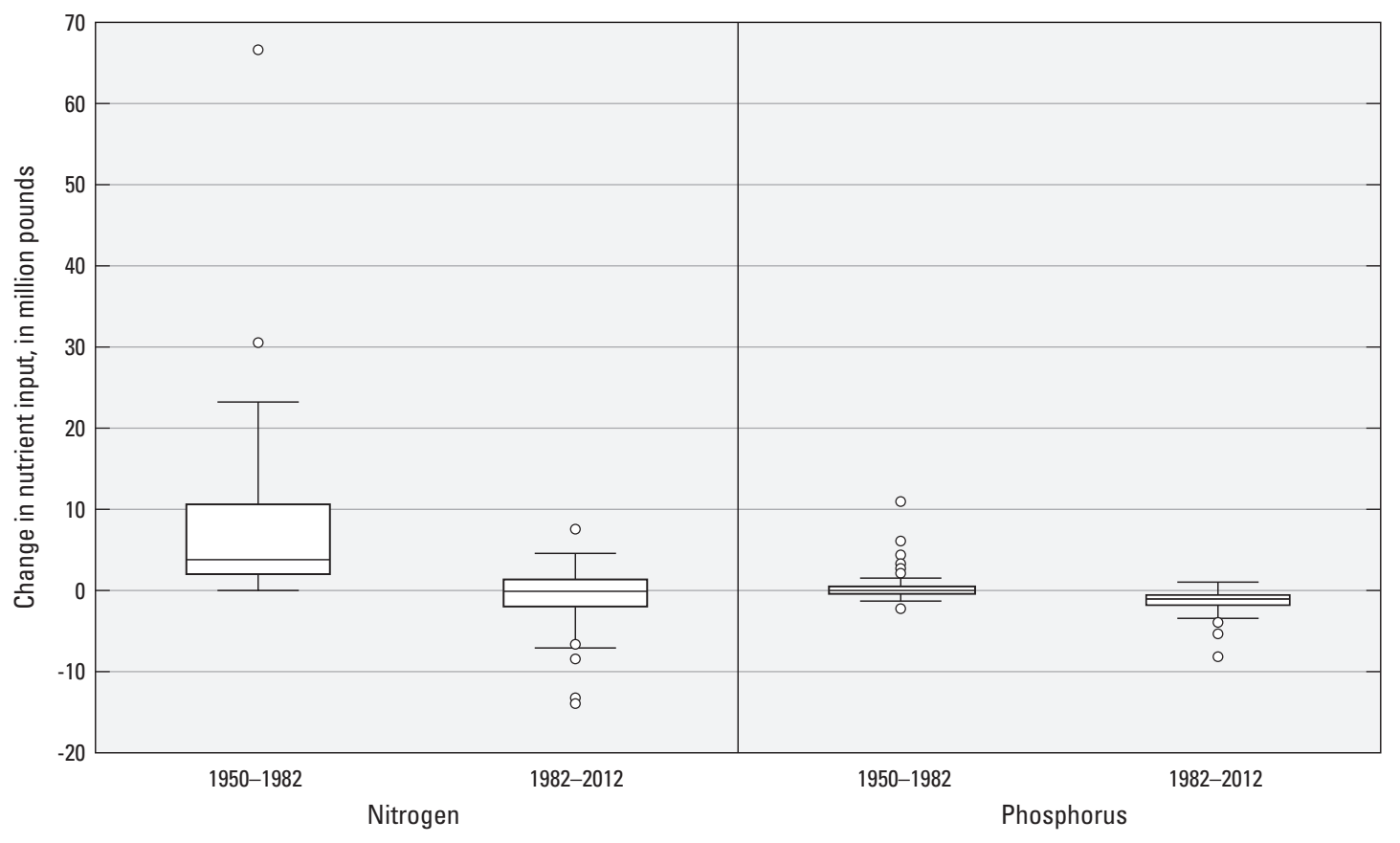

EXPLANATION

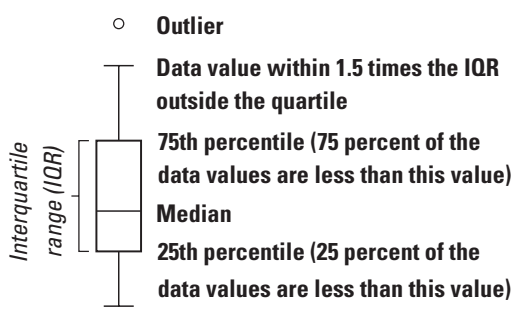

Figure 5. Range and variability of the change in agricultural $A$, nitrogen inputs, and $B$, phosphorus inputs from 1950-82 and 1982-2012 in the Chesapeake Bay watershed at the 8-digit hydrologic unit (HUC8) scale.

throughout the watershed during this period are also shown in figure 6. For example, manure-N inputs in the upper part of the Susquehanna region declined by about 30 million pounds, whereas manure-N inputs in HUC8s in the lower Susquehanna region increased by about 26 million pounds. The Potomac region also experienced a shift in the spatial distribution of manure inputs, in this case from the eastern HUC8s to the western HUC8s.

\section{Agricultural Land Use and Farming Practices}

In 1950 , there were about 23.3 million acres $\left(36,500 \mathrm{mi}^{2}\right)$ of land in farms in the Chesapeake Bay watershed, of which 3.4 million acres were in permanent pasture and 11.2 million acres were in cropland. Sixty-seven percent of cropland was further categorized as harvested cropland. Between 1950 and 1982, acres of land in farms declined 37 percent, acres of land in permanent pasture declined 60 percent, and acres of total cropland ("harvested cropland" + "pastured cropland" + "other cropland") declined 21 percent. The amount of cropland and the amount of land in farms continued to decline between 1982 and 2012, whereas acres of permanent pasture increased (table 7). Farms lost an additional 13 percent of land area overall, with steeper declines in cropland. The amount of total cropland declined to a greater degree than did the amount of harvested cropland.

The distinction between total cropland and harvested cropland is relevant for understanding patterns in manure and fertilizer inputs. The COA's "harvested cropland" category includes only the acreage from which crops were harvested and (or) hay was cut in a given Census year. The "total cropland" category also includes land on which crops were planted but failed to mature, as well as additional lands that could have been used for crops but were not in the given Census 


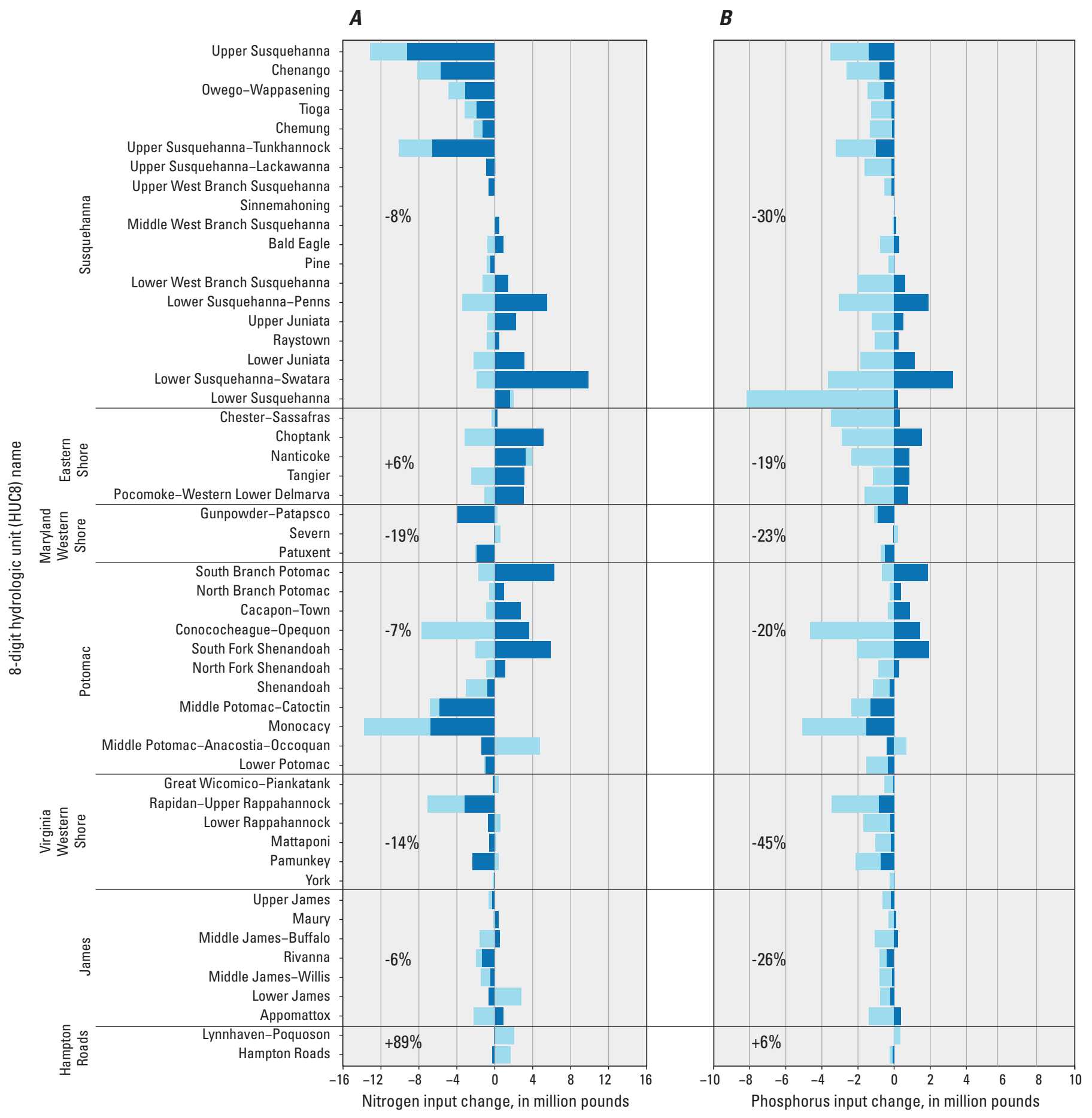

EXPLANATION

Fertilizer Manure

Figure 6. Change in agricultural $A$, nitrogen inputs, and $B$, phosphorus inputs for each 8-digit hydrologic unit (HUC8) in the Chesapeake Bay watershed from 1982 to 2012. [Note difference in scale of $x$-axes. Values represent the net percent (\%) change in nitrogen and phosphorus inputs for each region.] 
Table 7. Changes in farmland area (acres) in the Chesapeake Bay watershed, 1950-2012 (LaMotte, 2015).

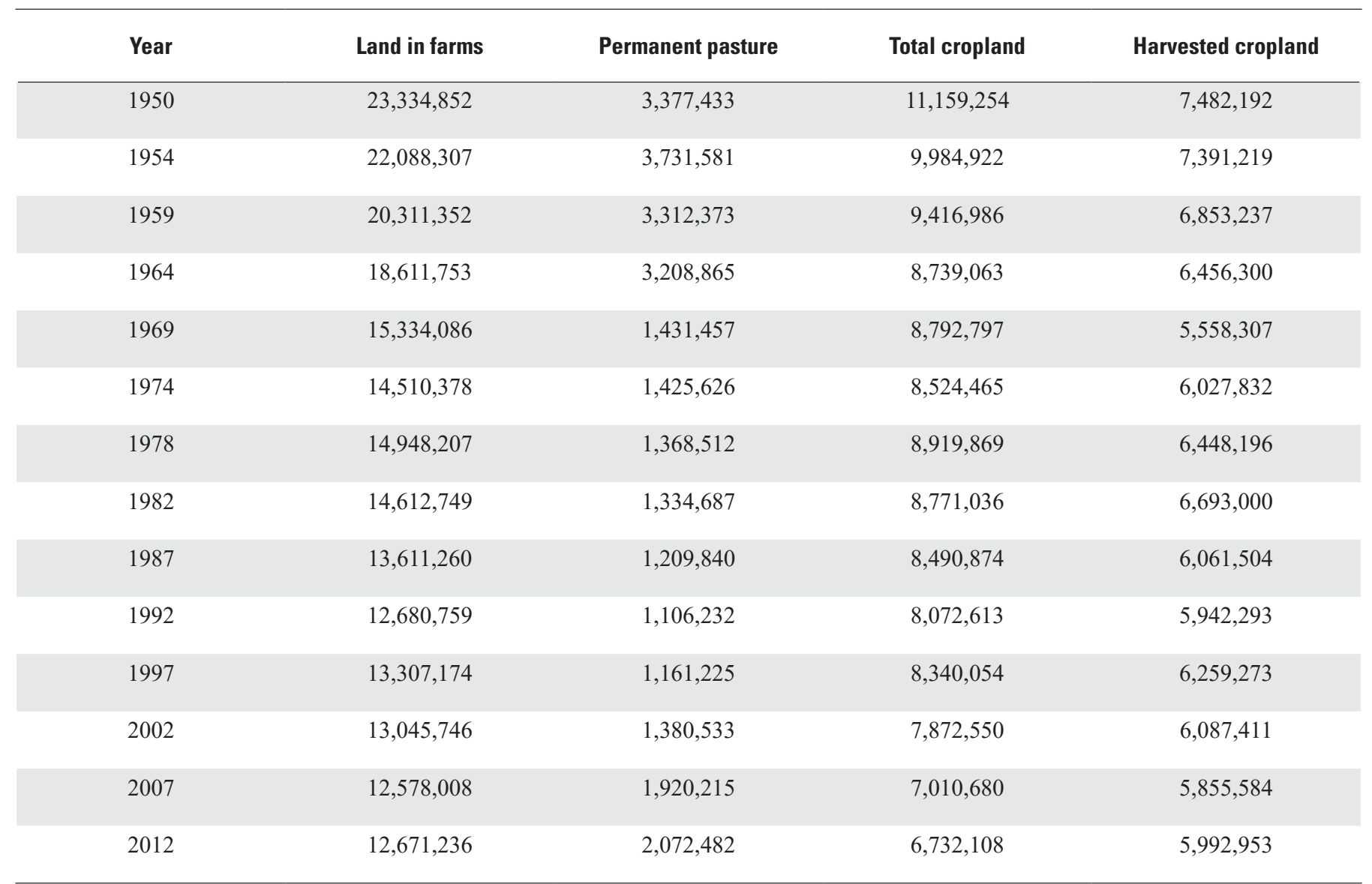

year (U.S. Department of Agriculture, National Agricultural Statistics Service, 2014). Where manure availability exceeds crop need, it may be applied to other cropland and pasture in addition to harvested cropland (MacDonald and others, 2009; Ribaudo and others, 2003; Kellogg and others, 2000). However, purchasing fertilizer in excess of crop need has an economic cost. Thus, changes in fertilizer inputs may be more closely tied to harvested cropland than to total cropland.

Of the 789,000 acres of harvested cropland acreage lost in the watershed between 1950 and 1982, the vast majority (637,000 acres, or 81 percent) was lost from the Susquehanna region of the watershed. These losses and additional losses from the Potomac, James, and Maryland Western Shore regions were partly counteracted by gains in the Eastern Shore and the Virginia Western Shore regions (table 8).

The same patterns were observed at the HUC8 scale: acres of harvested cropland increased in just 12 of the 53 HUC8s from 1950 to 1982, 10 of which were located in either the Eastern Shore or Virginia Western Shore regions. The period from 1982 to 2012 also showed increases in 12 of the 53 HUC8s. However, spatial variability shifted: previous gains in harvested cropland were reversed on the Eastern Shore and Virginia Western Shore, and increases were instead distributed among the Susquehanna (three HUC8s), James (three HUC8s), and Potomac (six HUC8s) regions. The continuing urbanization of the Maryland Western Shore and the Hampton Roads (Virginia) regions was reflected in additional losses of more than 30 percent of harvested cropland between 1982 and 2012.

Harvested cropland in the Chesapeake Bay watershed is divided among approximately 25 crop types (LaMotte, 2015). Six of these - barley, corn, hay, oats, soybeans, and wheat accounted for between 96 and 99 percent of acres harvested in any given Census year (table 9). In this context, "acres harvested" represents the sum of acres reported for each crop in the COA whereas "harvested cropland" represents the acres of cropland that are allocated to harvested crops each year. Harvesting more than one crop each year on the same acreage (double cropping) can result in more "acres harvested" than "harvested cropland."

Between 1950 and 2012, the prevalence of barley, oats, and wheat declined throughout the watershed, whereas the proportion of harvested acres dedicated to corn, hay, and soybeans increased from 67 to 88 percent of all acres harvested. Although the remaining 19 crops accounted for 1 percent or less of acres harvested in the Chesapeake Bay watershed, some of these were more prominently represented at local scales. Between 1950 and 2012, harvested cropland declined by about 20 percent, whereas acres harvested declined 11 percent. In other words, more intensive use of cropland may have 
Table 8. Changes in spatial variability of harvested cropland in the Chesapeake Bay watershed in 1950, 1982 , and 2012.

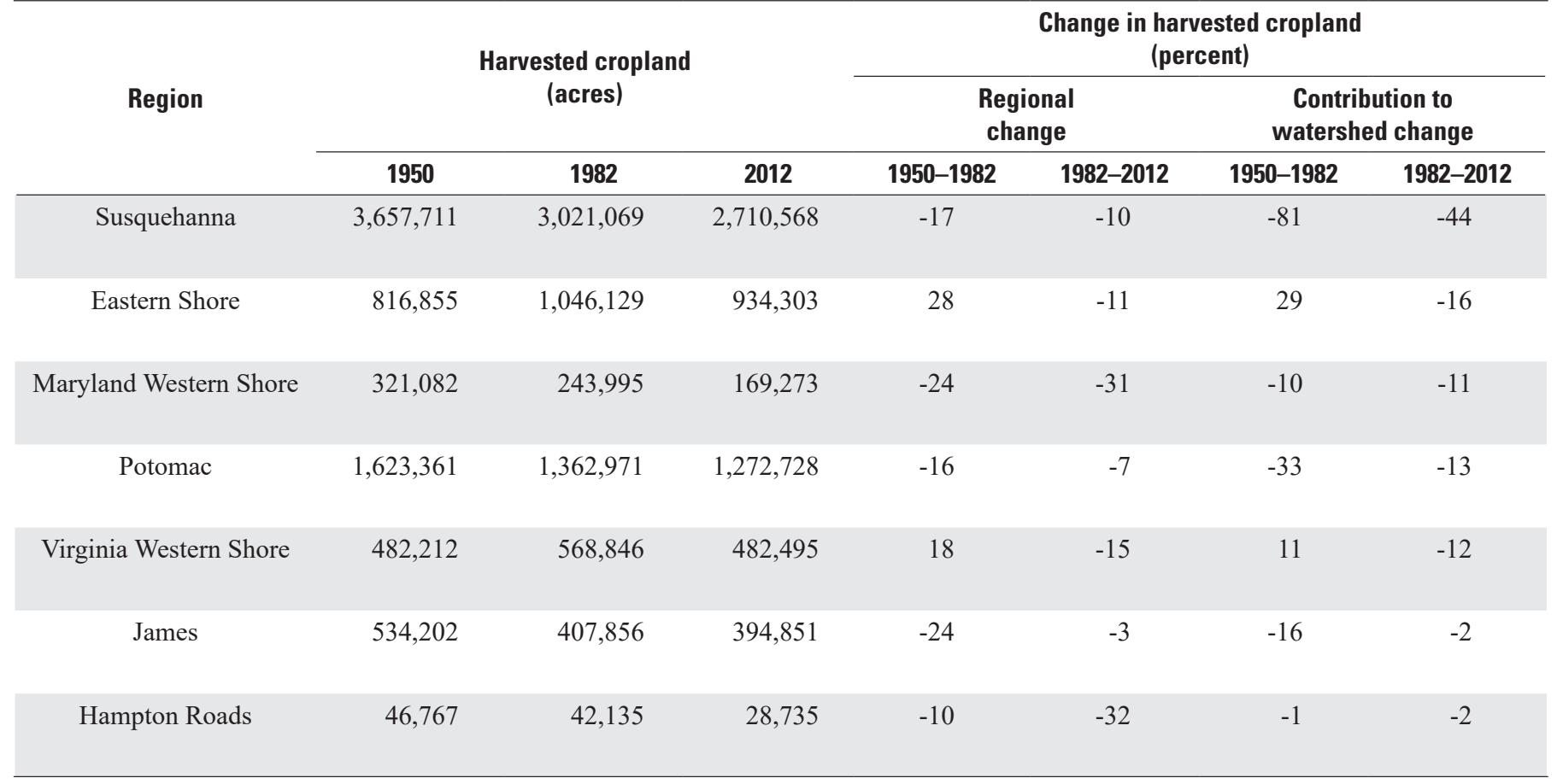

Table 9. Percentage of acres harvested for six dominant crop types in the Chesapeake Bay watershed, $1950-2012$.

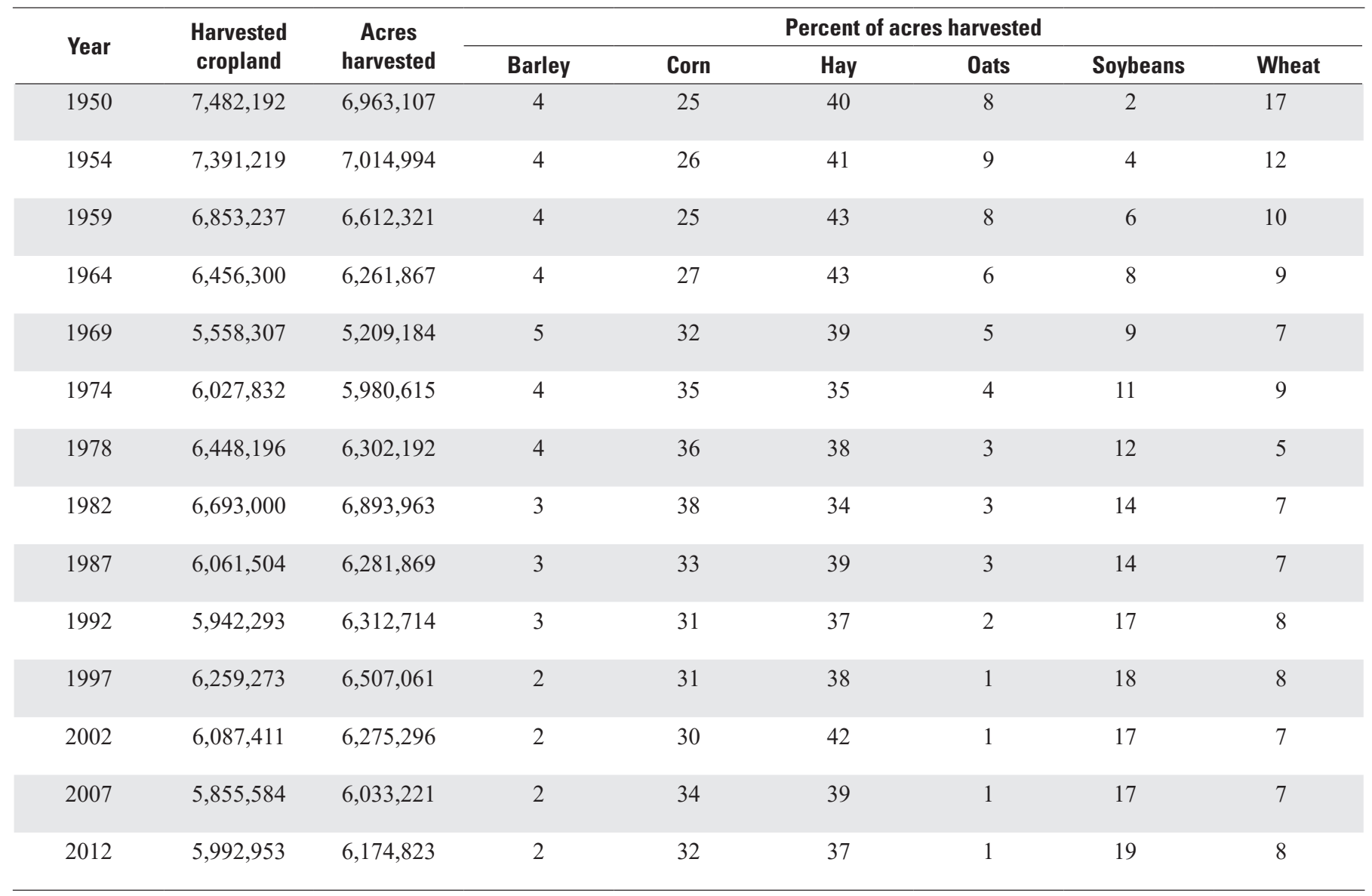


partially compensated for the reduction of agricultural land allocated to crop production in the watershed.

Patterns of nutrient inputs and decisions regarding crop cultivation may be affected by the magnitude of animal biomass, as well as by the production of different animal types. Biomass (in AUs) was relatively stable in the watershed between 1950 and 2012, despite the declines in farmland in general, and in permanent pasture acreage in particular, that occurred. Whereas changes in animal biomass between Census years ranged from -11 to +23 percent, the net change over the entire period was less than 1 percent. The proportion of AUs represented by cows declined by about 11 percent from 1950 to 2012, whereas the proportion of AUs represented by poultry increased by about 14 percent (table 10). The concentration of nutrients varies among animal types; for example, poultry manure contains a higher $P$ fraction per pound than cow manure (American Society of Agricultural and Biological Engineers, 2005).

The coupled nature of crop and animal production is reflected in the changing nature of corn and hay production across the watershed. Whereas acres harvested of corn grown for grain ("grain corn") changed less than 1 percent between 1950 and 2012, cultivation of corn grown for silage ("silage corn") increased from 295,518 to 491,518 acres harvested, or about 66 percent. Similarly, in 1950, silage hay accounted for 1 percent of all hay acres harvested. By 2012, that proportion had increased to 21 percent.

The spatial variability in cultivation of both major crop groups and animal groups in 1982 and 2012 is shown in figure 7. Poultry and poultry feed (grain corn and soybeans) dominate agricultural land on the Eastern Shore; about 45 percent of the entire watershed's poultry inventory, 35 percent of its soybean acreage, and 24 percent of its grain corn acreage were produced in this region in 2012. Cultivation of forage and silage crops was more broadly distributed across the remaining five regions, as were cow populations. The Lower Susquehanna HUC8 contains large proportions of all three animal groups (including 41 percent of the entire watershed's hog inventory) and all four crop types.

Table 10. Annual percentage of animal biomass (in animal units) for the five major animal types produced in the Chesapeake Bay watershed, 1950-2012.

\begin{tabular}{|c|c|c|c|c|c|c|}
\hline \multirow[t]{2}{*}{ Year } & \multirow[t]{2}{*}{ Animal units } & \multicolumn{5}{|c|}{$\begin{array}{l}\text { Animal biomass } \\
\text { (percent) }\end{array}$} \\
\hline & & All cows & All poultry & Horses & Sheep & Hogs \\
\hline 1950 & $2,946,787$ & 74 & 4 & 7 & 2 & 14 \\
\hline 1954 & $3,003,566$ & 82 & 3 & 1 & 1 & 13 \\
\hline 1959 & $2,984,522$ & 80 & 2 & 3 & 2 & 13 \\
\hline 1964 & $2,665,731$ & 86 & 3 & 0 & 1 & 10 \\
\hline 1969 & $3,281,758$ & 65 & 22 & 2 & 1 & 10 \\
\hline 1974 & $2,929,712$ & 79 & 8 & 2 & 1 & 10 \\
\hline 1978 & $2,965,039$ & 73 & 10 & 3 & 1 & 14 \\
\hline 1982 & $3,239,750$ & 72 & 11 & 3 & 1 & 13 \\
\hline 1987 & $3,133,925$ & 69 & 14 & 3 & 1 & 13 \\
\hline 1992 & $3,181,345$ & 67 & 15 & 3 & 1 & 14 \\
\hline 1997 & $3,216,803$ & 65 & 18 & 3 & 0.5 & 13 \\
\hline 2002 & $3,160,248$ & 63 & 17 & 5 & 0.5 & 14 \\
\hline 2007 & $3,055,029$ & 62 & 19 & 5 & 0.4 & 14 \\
\hline 2012 & $2,963,812$ & 63 & 18 & 6 & 0.5 & 13 \\
\hline
\end{tabular}



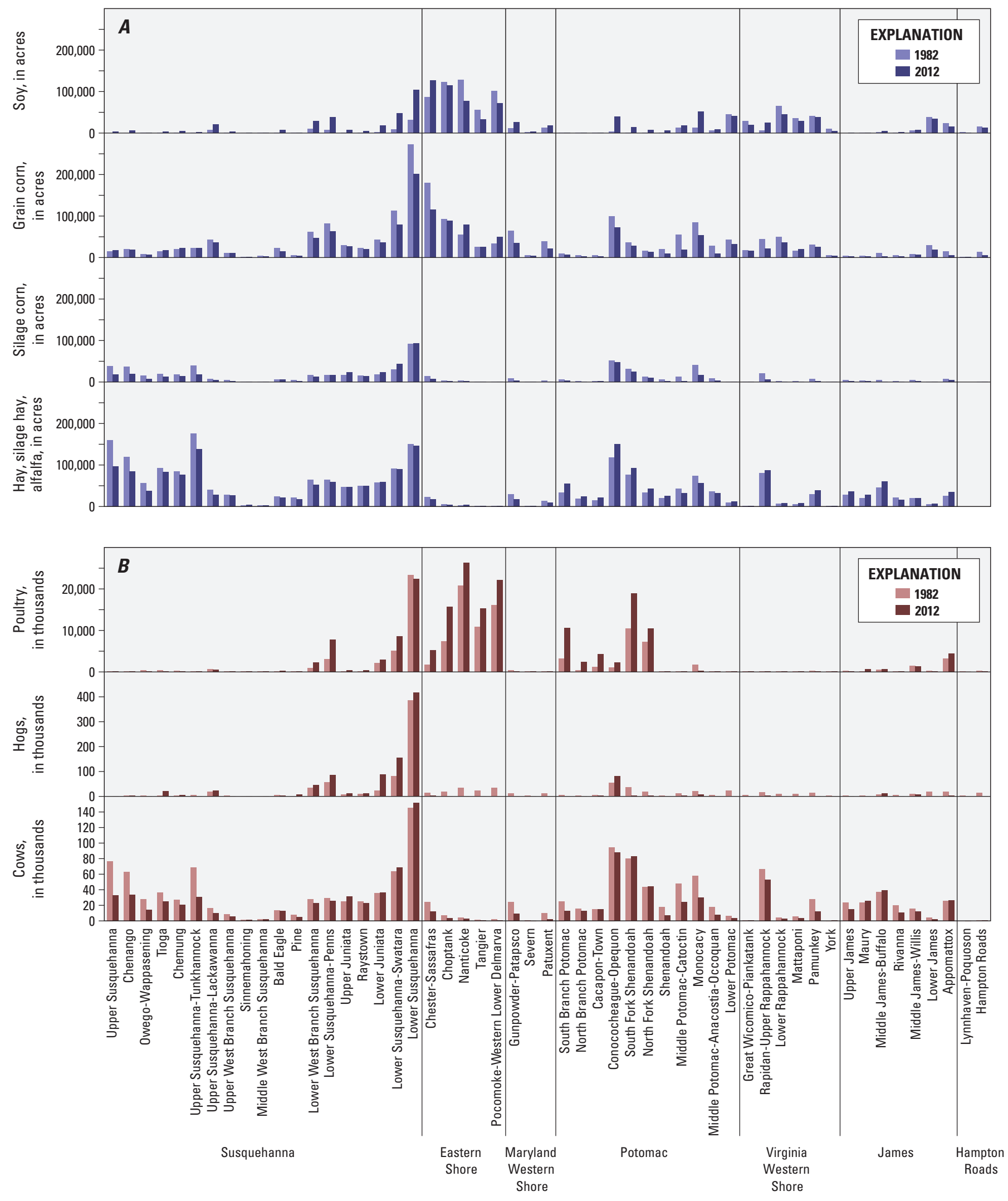

8-digit hydrologic unit (HUC8) name

Figure 7. Spatial variability of $A$, major crop groups, and $B$, major animal groups in the Chesapeake Bay watershed in 1982 and 2012. [Note difference in scale of $x$-axes.] 


\section{Nutrient Input Intensity}

Declines over time in pasture and cropland, combined with stable or increasing animal inventories and fertilizer inputs and the changing proportion of crops harvested per acre of harvested cropland, indicate that the amount of $\mathrm{N}$ and $\mathrm{P}$ input per acre of total cropland ("nutrient input intensity") may have increased over time. The spatial pattern of nutrient input intensity on agricultural acreage across the watershed in 1982 is shown in figure 8 . N input intensity increased in all 7 regions of the watershed (table 11), and in 44 HUC8s between 1982 and 2012 (fig. 9). During the same period, $\mathrm{P}$ input intensity increased in 4 regions and 22 HUC8s across those regions. Five of the HUC8s with increasing P input intensity were clustered in the Maryland Western Shore and the Hampton Roads (Virginia) regions, where sharp declines in agricultural land coincided with gains in fertilizer-P use associated with new residential development. Elsewhere, the input intensity of fertilizer-P declined whereas manure-P input intensity either increased (Susquehanna, Eastern Shore, Potomac, James) or was stable (Virginia Western Shore).

\section{Relating Agricultural Practices to Fertilizer and Manure Inputs}

Manure inputs in any given HUC8 are a direct result of local animal populations, therefore they are not expected to vary as a result of changes in either the amount of cropland or the crops being cultivated. However, because nutrient requirements differ among crop types, changes in fertilizer inputs over time may be more closely related to changes in crop production. This relation may be confounded by the availability of animal manure; where appropriate and economical, manure can reduce the need for commercial fertilizer (MacDonald and others, 2009). Alternatively, excess manure must be disposed of and may be spread on cropland in excess of crop nutrient need or transported to other areas.

Corn has a high $\mathrm{N}$ requirement relative to other major agronomic crops (Basden and others, 2006), and it is often suggested that increases in corn cultivation in particular result in increased fertilizer-N inputs. In the case of the Chesapeake Bay watershed, fertilizer-N inputs increased each year from 1950 to 1974 on harvested cropland across all HUC8s, independent of the amount of acreage in any given crop, including corn. However, commercial fertilizer-N usage leveled off at the watershed scale during the mid-1970s, indicating a shift that may have tied fertilizer inputs more closely to crop need.

When data prior to 1974 were excluded from the analysis $^{7}, \mathrm{HUC} 8 \mathrm{~s}$ with a greater proportion of harvested cropland in grain corn tended to have greater fertilizer-N input intensity per acre of harvested cropland, but the relation was weak but significant $\left(\mathrm{r}^{2}=0.18, \mathrm{p}<0.001\right)$ and visual inspection

\footnotetext{
${ }^{7}$ Lynnhaven-Poquoson was also excluded; its fertilizer-N application intensity is an order of magnitude greater than any other HUC8 in the post-1974 period.
}

revealed a deviation from this tendency in the more urbanized HUC8s. When the 13 predominantly urban HUC8s identified previously were excluded, this relation improved $\left(\mathrm{r}^{2}=0.31, \mathrm{p}<0.001\right)$ (fig. $\left.10 \mathrm{~A}\right)$. In contrast, there was a very slight (but still significant) negative correlation between silage corn cultivation and fertilizer-N input intensity $\left(\mathrm{r}^{2}=0.12\right.$, $\mathrm{p}<0.001$ ) (fig. $10 B$ ). Silage corn tends to be grown in close proximity to cow production, and its high $\mathrm{N}$ requirements may be met more by applications of readily available manure than by the purchase of inorganic fertilizer.

\section{Effects of Best Management Practice (BMP) Implementation on Manure and Fertilizer Inputs}

This section describes the aggregated expected effect of the four BMPs that affect nutrient inputs to land. Landuse change BMPs, dairy precision feeding and (or) forage management, and manure transport can have direct effects on both $\mathrm{N}$ and $\mathrm{P}$ inputs; poultry phytase reduces the $\mathrm{P}$ content of manure. Local manure transport can reduce manure input in one HUC8 while increasing it in another HUC8. Reports of manure transport implementation indicate that of the approximately 2.6 billion pounds of poultry manure transported between 1998 and 2012, about 35 percent was transported out of the Chesapeake Bay watershed (Devereux and others 2017).

\section{Expected Reductions in Fertilizer and Manure Inputs}

BMPs were expected to have a relatively minor impact on $\mathrm{N}$ and $\mathrm{P}$ inputs from manure and fertilizer between 1985 and 2012. The modeling scenarios generated by use of the CBP's Phase 5.3.2 Scenario Builder indicated that a reduction in $\mathrm{N}$ inputs to land of about 41 million pounds (3.6 percent), and 9 million pounds (3.9 percent) in P inputs to land would have occurred in the Chesapeake Bay watershed between 1985 and 2012 without any implementation of BMPs (No Action scenario). It is important to note that Scenario Builder estimates $\mathrm{N}$ and $\mathrm{P}$ inorganic fertilizer based on crop need, resulting in different estimates of the magnitude of fertilizer use than those described earlier in this report. In spite of this discrepancy, Scenario Builder simulations are useful for estimating relative (percent) changes in fertilizer use due to changes on the landscape.

When reported BMP implementation was considered (Progress scenario), an additional 0.8-percent decrease in $\mathrm{N}$ inputs (9 million pounds), and an additional 5.2-percent decrease in P inputs (12 million pounds) were predicted (fig. 11). Lower fertilizer usage accounted for 8.9 of the expected 9-million-pound additional reduction in agricultural $\mathrm{N}$ inputs. Some of the nutrient reduction is due to the loss of agricultural land, which has the effect of reducing fertilizer inputs. With fewer crops, there is less fertilizer purchased and 
$\boldsymbol{A}$

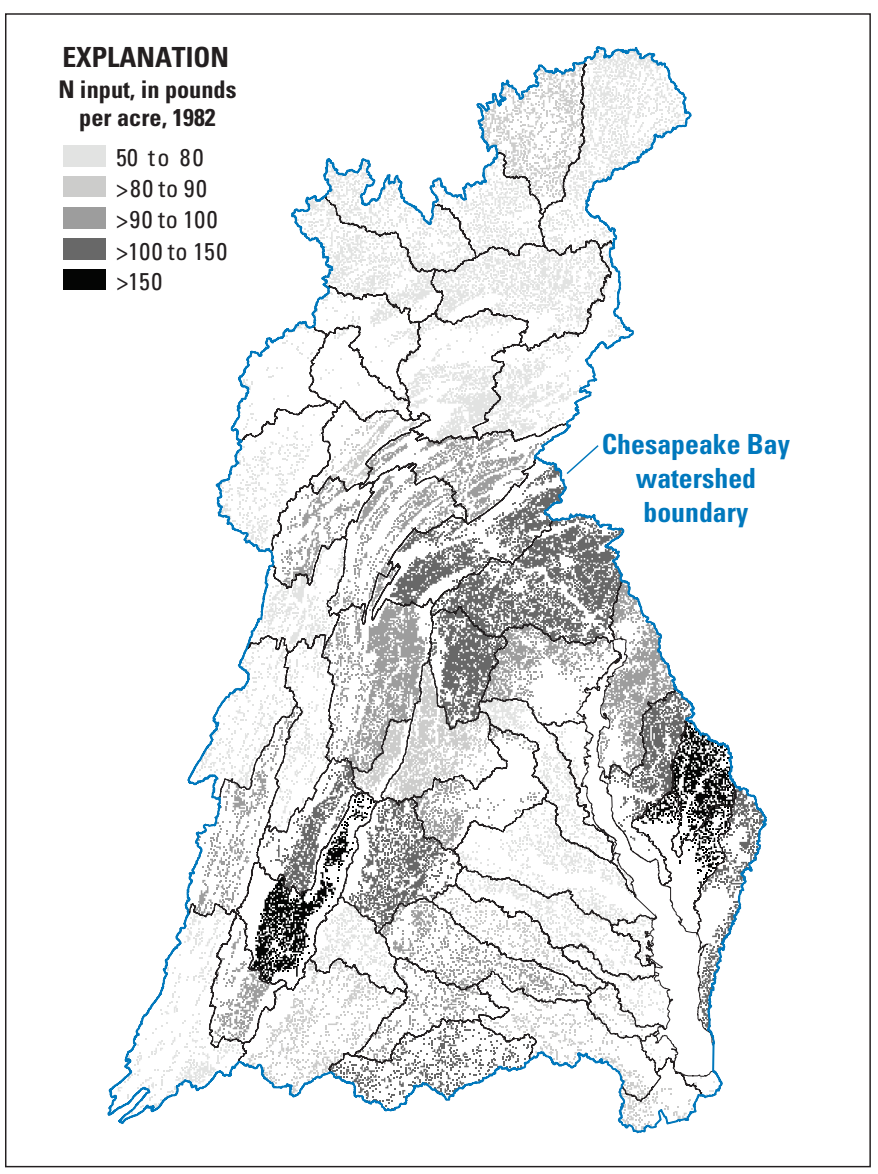

B

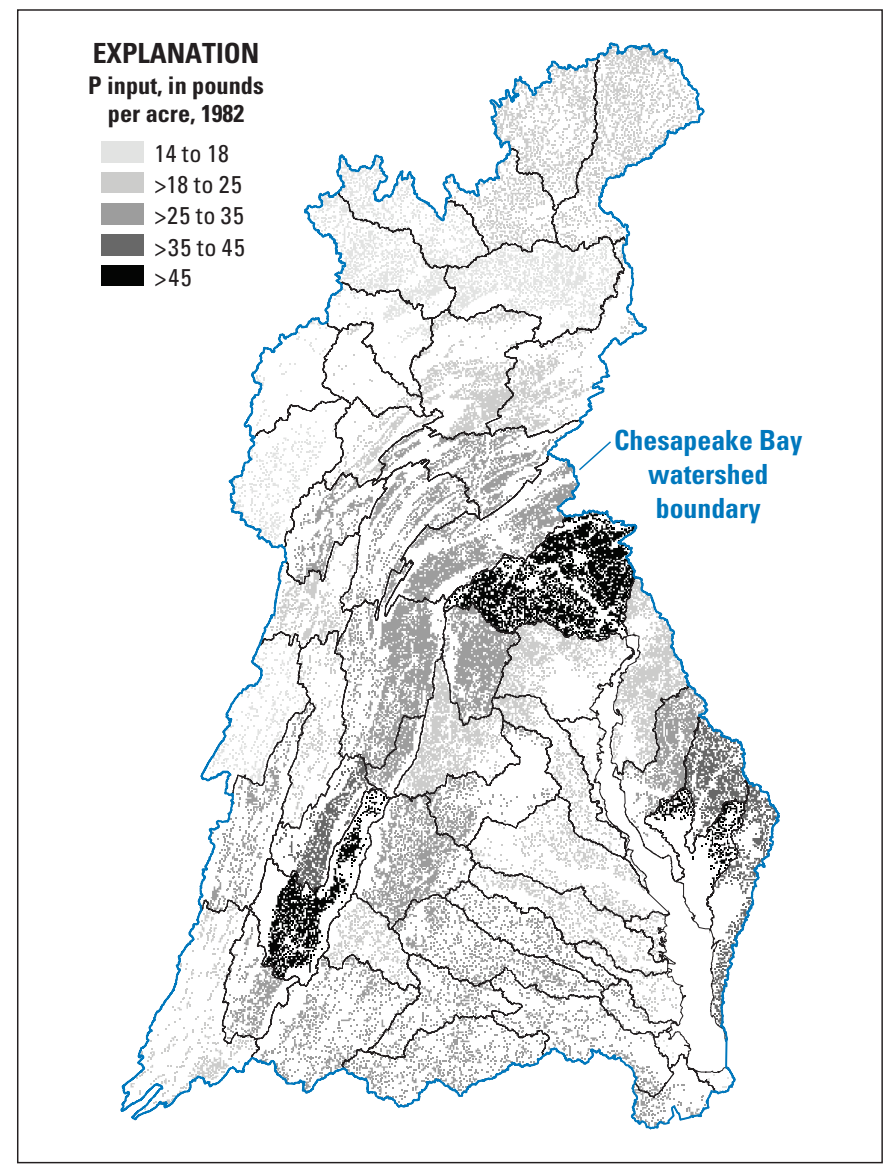

Figure 8. Input intensity of $A$, nitrogen (N) and $B$, phosphorus (P) on agricultural acres in the Chesapeake Bay watershed in 1982. [Inputs are the sum of manure and fertilizer in pounds per acre of cropland.]

applied. Where animal populations do not change, the manure is still applied to land, sometimes at a higher application rate than is required by the crop.

Reductions in manure-P usage were solely responsible for the expected additional reduction in agricultural $\mathrm{P}$ inputs; the model actually simulated a small (3-percent) increase in fertilizer-P inputs as a result of BMP implementation. This result reflects the simulated effect of manure transport out of the watershed; farmers may replace manure $\mathrm{P}$ with commercial fertilizer according to crop need.

BMPs were expected to generate negligible additional change (less than 0.5 percent) in $\mathrm{N}$ inputs in 33 out of the 53 HUC8s in the Chesapeake Bay watershed. Among the remainder, BMPs reduced $\mathrm{N}$ inputs by anywhere from 0.6 to 4 percent, with the greatest reduction expected in the Choptank HUC8 (table 12).

Lower fertilizer-N inputs were the sole driver of these small expected $\mathrm{N}$ reductions - more than compensating for increasing manure-N inputs - in five of the seven Chesapeake regions (table 13), and were the primary driver (accounting for more than half) of expected $\mathrm{N}$-input reductions in $41 \mathrm{HUC} 8 \mathrm{~s}$ distributed across all regions of the watershed. The Progress scenario predicted increased manure- $\mathrm{N}$ inputs as a result of BMP implementation in 25 HUC8s. This result is likely due to the transport of manure into these HUC8s from basins with excess manure production.

In the Susquehanna and Eastern Shore regions, expected $\mathrm{N}$ reductions were almost evenly split between manure and fertilizer sources. In the Susquehanna region, larger than expected manure-N reductions in the Swatara and Lower Susquehanna HUC8s accounted for the greater influence of manure on $\mathrm{N}$ reductions in this region. In the Eastern Shore region, larger than expected decreases in manure- $\mathrm{N}$ inputs in the Nanticoke, Tangier, and Pocomoke-Western Lower Delmarva countered relatively small increases in manure- $\mathrm{N}$ inputs in the Chester-Sassafras and Choptank HUC8s.

Expected reductions in $\mathrm{P}$ inputs from implementation of these four BMPs (poultry feed additives, dairy precision feeding, manure transport, and land-use change) ranged from no appreciable change in $17 \mathrm{HUC} 8$ s up to an additional 51-percent reduction in the Sinnemahoning HUC8. In contrast to $\mathrm{N}$-input changes, decreases in manure-P inputs were the 
Table 11. Intensity of agricultural nutrient inputs to seven major regions in the Chesapeake Bay watershed in 1950, 1982 , and 2012.

\begin{tabular}{|c|c|c|c|c|c|c|}
\hline \multirow[t]{2}{*}{ Region } & \multicolumn{3}{|c|}{$\begin{array}{c}\text { Nitrogen-input intensity } \\
\text { (pounds per acre of total cropland) }\end{array}$} & \multicolumn{3}{|c|}{$\begin{array}{l}\text { Phosphorus-input intensity } \\
\text { (pounds per acre of total cropland) }\end{array}$} \\
\hline & 1950 & 1982 & 2012 & 1950 & 1982 & 2012 \\
\hline Eastern Shore & 31 & 123 & 144 & 22 & 35 & 31 \\
\hline Potomac & 45 & 104 & 140 & 21 & 29 & 34 \\
\hline Virginia Western Shore & 45 & 90 & 111 & 26 & 27 & 21 \\
\hline James & 41 & 88 & 133 & 19 & 26 & 31 \\
\hline
\end{tabular}

\section{$\boldsymbol{A}$}

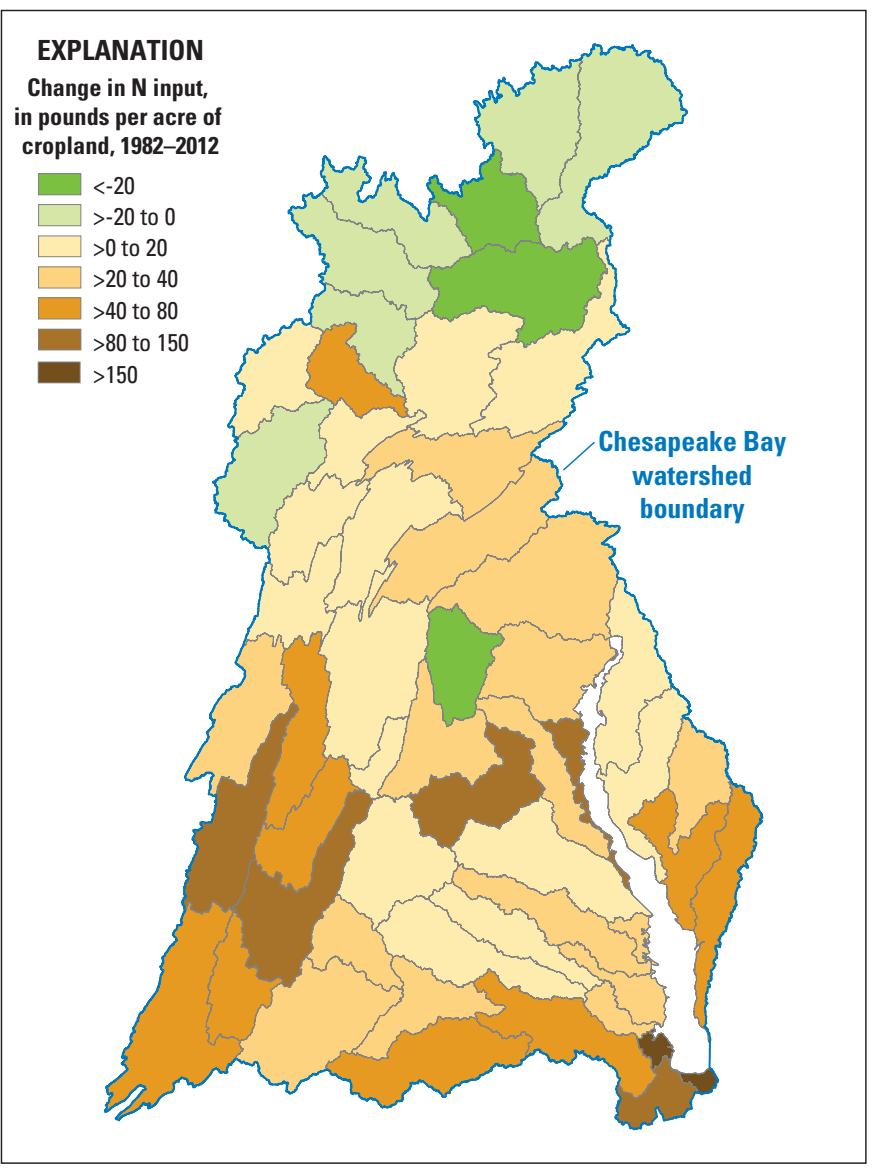

$\boldsymbol{B}$

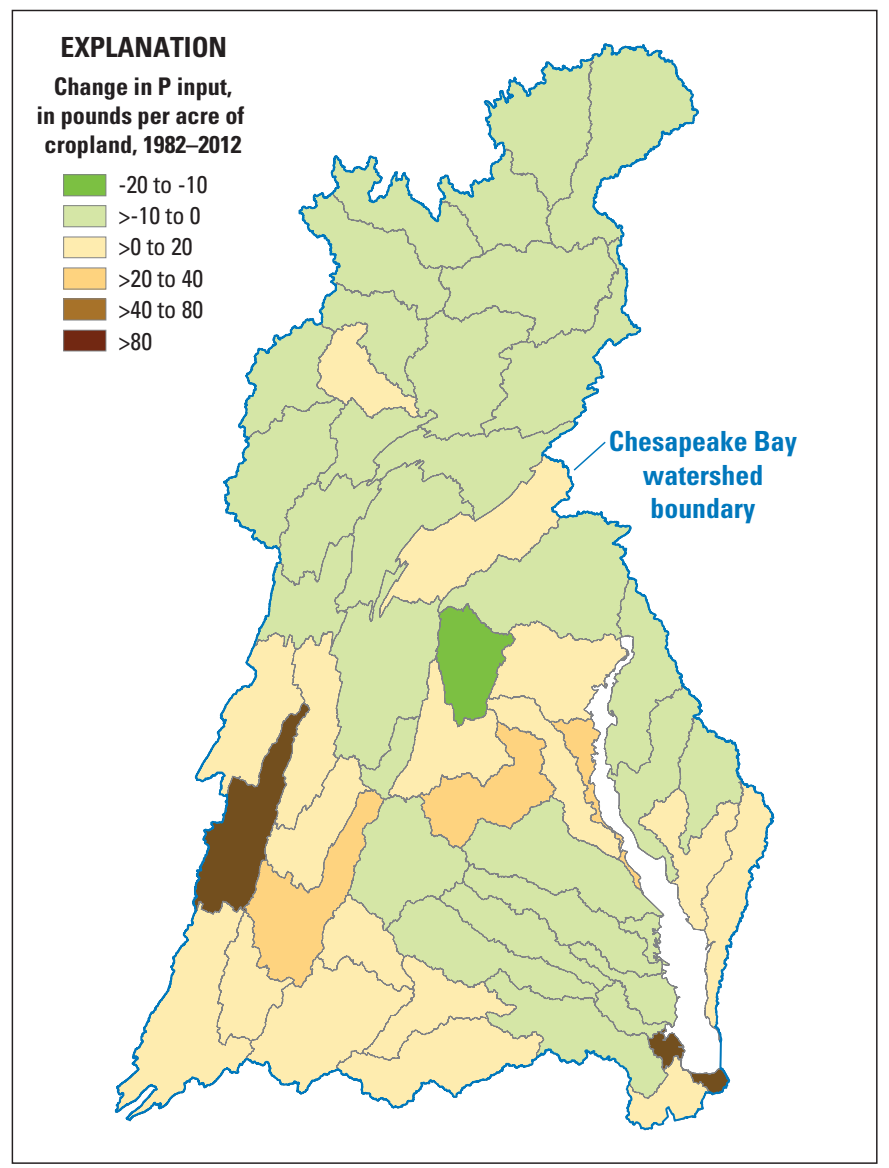

Figure 9. Input intensity change from 1982 to 2012 for $A$, nitrogen (N) and $B$, phosphorus (P) in the Chesapeake Bay watershed. [Inputs are the sum of manure and fertilizer in pounds per acre of cropland.] 

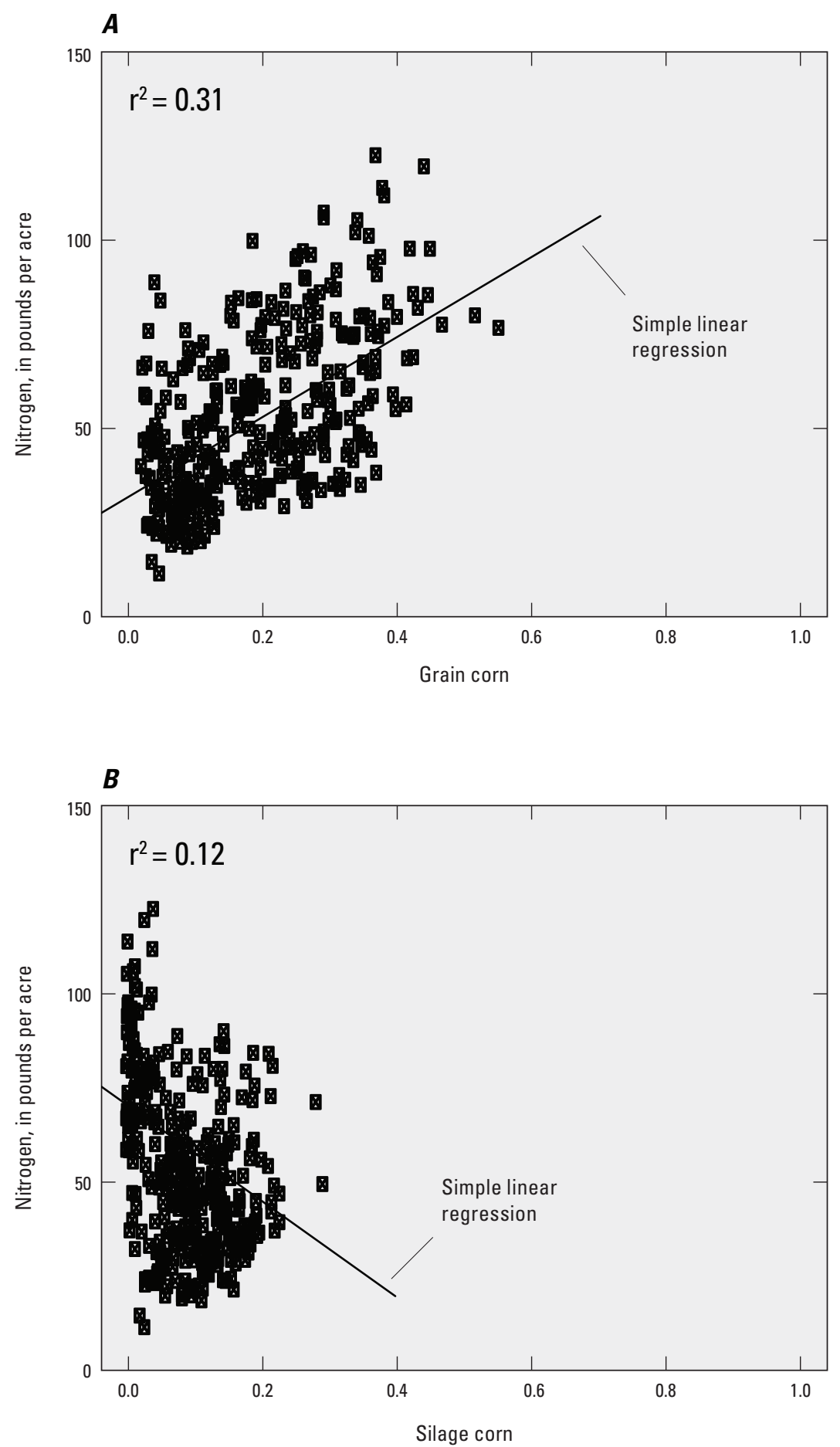

Figure 10. Nitrogen fertilizer use on harvested cropland by proportion of cropland devoted to $A$, grain corn, and $B$, silage corn in the Chesapeake Bay watershed. [Data are by Census of Agriculture for each 8-digit hydrologic unit (HUC8) from 1974 to 2012. Predominantly urban HUC8s are excluded.] 

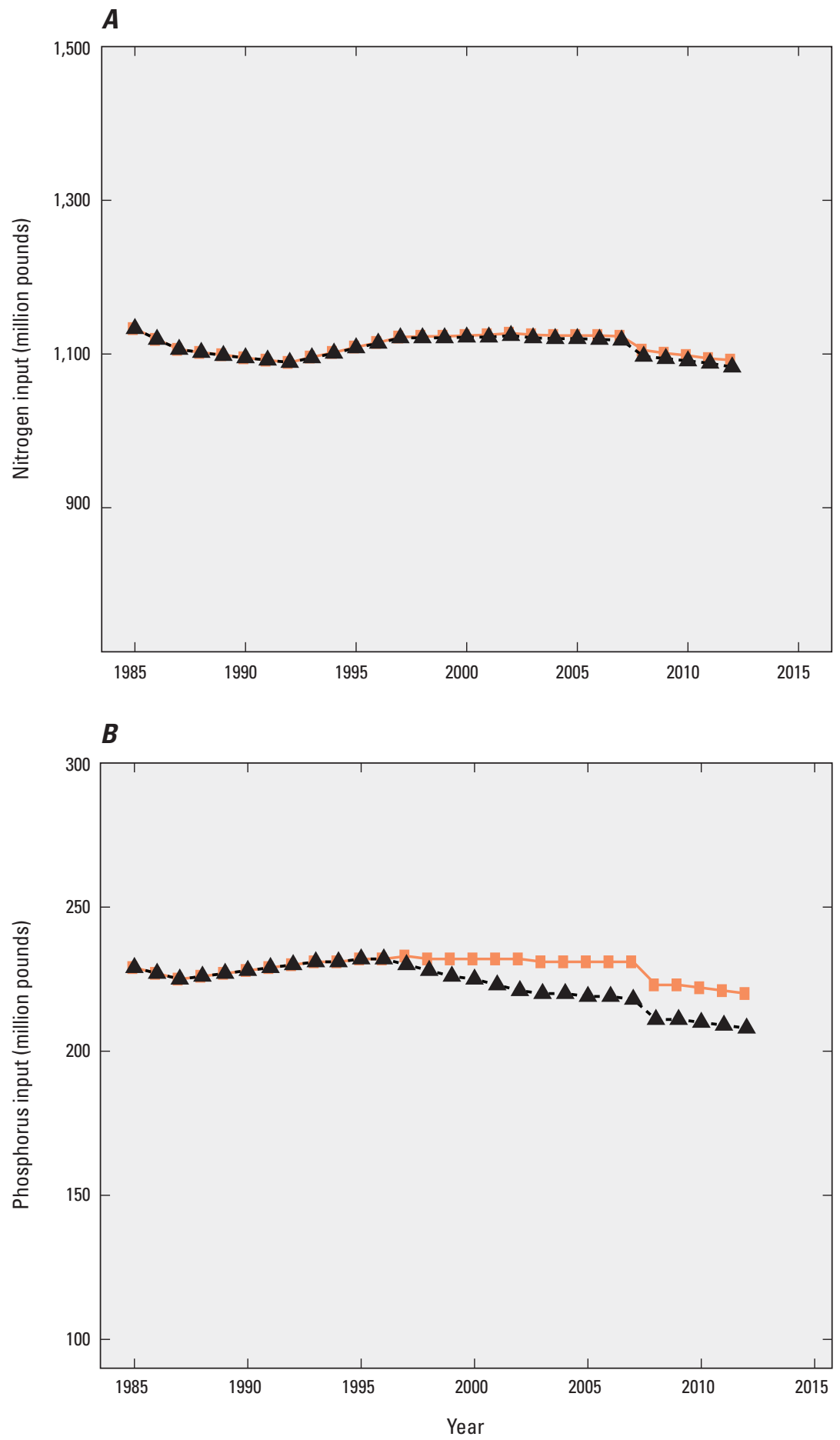

EXPLANATION

- No BMPs

- W- With BMPs

Figure 11. Expected effect of best management practices (BMPs) on $A$, nitrogen (N) and $B$, phosphorus (P) applications to land in the Chesapeake Bay watershed, 1985-2012. [Note difference in scales of y axes.] 
Table 12. Expected change in nitrogen (N) and phosphorus (P) applications in the Chesapeake Bay watershed with and without best management practice (BMP) implementation, 1985-2012.

[HUC8, 8-digit hydrologic unit; ND, not determined]

\begin{tabular}{|c|c|c|c|c|c|}
\hline \multirow[t]{2}{*}{ Region } & \multirow[t]{2}{*}{ HUC8 name } & \multicolumn{2}{|c|}{$\begin{array}{c}\text { Change in N applied, 1985-2012 } \\
\text { (percent) }\end{array}$} & \multicolumn{2}{|c|}{$\begin{array}{c}\text { Change in P applied, 1985-2012 } \\
\text { (percent) }\end{array}$} \\
\hline & & Without BMPs & With BMPs & Without BMPs & With BMPs \\
\hline \multirow{19}{*}{ Susquehanna } & Upper Susquehanna & -41 & -42 & -48 & -49 \\
\hline & Chenango & -37 & -38 & -42 & -42 \\
\hline & Owego-Wappasening & -36 & -37 & -45 & -45 \\
\hline & Tioga & -9 & -9 & -6 & -8 \\
\hline & Chemung & -23 & -23 & -29 & -29 \\
\hline & Upper Susquehanna-Tunkhannock & -28 & -28 & -40 & -40 \\
\hline & Upper Susquehanna-Lackawanna & -8 & -9 & -2 & -3 \\
\hline & Upper West Branch Susquehanna & -8 & -8 & -22 & -22 \\
\hline & Sinnemahoning & 169 & 169 & 225 & 173 \\
\hline & Middle West Branch Susquehanna & ND & ND & ND & ND \\
\hline & Bald Eagle & 0 & -1 & 5 & 4 \\
\hline & Pine & ND & ND & ND & ND \\
\hline & Lower West Branch Susquehanna & -13 & -13 & 3 & 0 \\
\hline & Lower Susquehanna-Penns & -2 & -3 & 25 & 16 \\
\hline & Upper Juniata & 26 & 25 & 36 & 35 \\
\hline & Raystown & -4 & -4 & 1 & 0 \\
\hline & Lower Juniata & -3 & -4 & 6 & 2 \\
\hline & Lower Susquehanna-Swatara & 15 & 14 & 33 & 26 \\
\hline & Lower Susquehanna & -6 & -7 & -4 & -11 \\
\hline \multirow{5}{*}{ Eastern Shore } & Chester-Sassafras & -5 & -6 & 5 & 0 \\
\hline & Choptank & 26 & 22 & 22 & 12 \\
\hline & Nanticoke & 0 & -3 & -14 & -24 \\
\hline & Tangier & 6 & 3 & -5 & -19 \\
\hline & Pocomoke-Western Lower Delmarva & 6 & 5 & 6 & -6 \\
\hline \multirow{3}{*}{$\begin{array}{c}\text { Maryland } \\
\text { Western Shore }\end{array}$} & Gunpowder-Patapsco & -22 & -22 & -34 & -34 \\
\hline & Severn & ND & ND & ND & ND \\
\hline & Patuxent & -4 & -4 & -26 & -26 \\
\hline \multirow{11}{*}{ Potomac } & South Branch Potomac & 25 & 22 & 62 & 39 \\
\hline & North Branch Potomac & -3 & -3 & 17 & 8 \\
\hline & Cacapon-Town & 16 & 15 & 29 & 19 \\
\hline & Conococheague-Opequon & 4 & 3 & 5 & 2 \\
\hline & South Fork Shenandoah & 7 & 5 & 7 & -3 \\
\hline & North Fork Shenandoah & 8 & 6 & 2 & -6 \\
\hline & Shenandoah & -21 & -21 & -31 & -31 \\
\hline & Middle Potomac-Catoctin & -19 & -19 & -32 & -32 \\
\hline & Monocacy & -30 & -30 & -30 & -31 \\
\hline & Middle Potomac-Anacostia-Occoquan & 17 & 17 & -21 & -21 \\
\hline & Lower Potomac & 11 & 11 & -11 & -11 \\
\hline
\end{tabular}


Table 12. Expected change in nitrogen $(\mathrm{N})$ and phosphorus $(\mathrm{P})$ applications in the Chesapeake Bay watershed with and without best management practice (BMP) implementation, 1985-2012. - Continued

[HUC8, 8-digit hydrologic unit; ND, not determined]

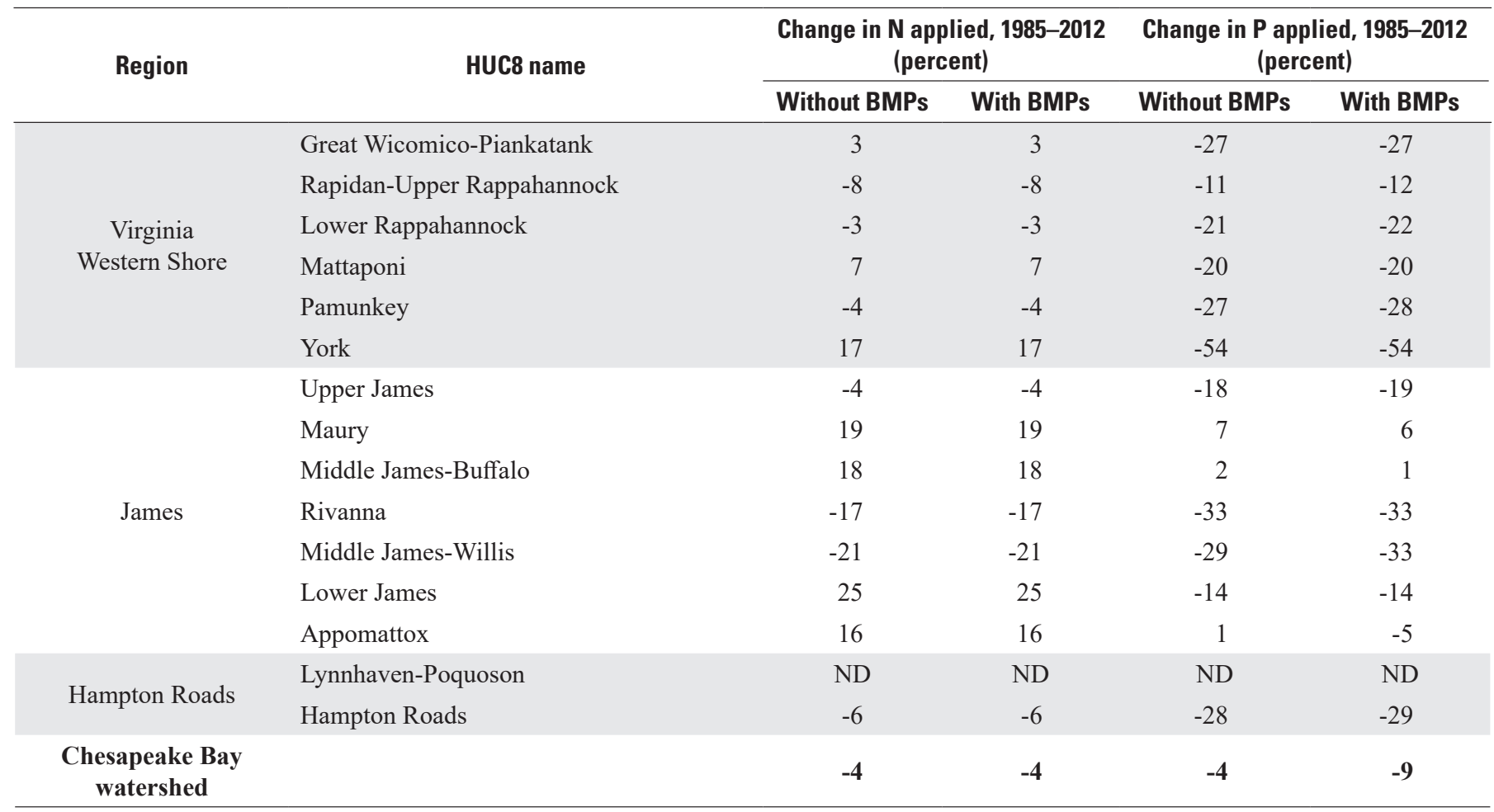

Table 13. Spatial variability in expected changes in manure and fertilizer inputs due to best management practice (BMP) implementation in the Chesapeake Bay watershed, 1985-2012.

[N, nitrogen; $\mathrm{P}$, phosphorus $]$

\begin{tabular}{|c|c|c|c|c|}
\hline \multirow[t]{2}{*}{ Region } & \multicolumn{4}{|c|}{$\begin{array}{l}\text { Change due to BMPs, 1985-2012 } \\
\text { (pounds) }\end{array}$} \\
\hline & Manure N & Fertilizer $\mathbf{N}$ & Manure P & Fertilizer $\mathbf{P}$ \\
\hline Eastern Shore & $-1,367,777$ & $-1,853,734$ & $-4,807,370$ & 435,302 \\
\hline Potomac & $1,716,842$ & $-4,702,115$ & $-3,449,915$ & $-256,347$ \\
\hline Virginia Western Shore & 71,244 & $-124,050$ & $-38,681$ & $-2,112$ \\
\hline Hampton Roads & 4,089 & $-9,348$ & $-8,175$ & 2,630 \\
\hline
\end{tabular}


sole driver of expected P reductions in 5 of the 7 Chesapeake regions and accounted for the majority of expected reductions in 42 HUC8s. Implementation of these BMPs was expected to increase fertilizer-P usage in all but 2 regions $^{8}$, and in 26 HUC8s distributed across all 7 regions of the watershed.

\section{Animal Best Management Practice (BMP) Implementation}

The reductions in manure- $\mathrm{N}$ and manure-P inputs described above can be fully attributed to animal BMPs, as only these BMPs affect nutrient concentrations and (or) amounts of manure. However, based on BMP implementation reported to the CBP (Devereux and others, 2017), rates for dairy precision feeding/forage management were so low that it would be unlikely that they affected manure nutrient concentrations (table 14). The 100-percent implementation level of poultry phytase is more likely to have affected manure-P reductions, although increasing poultry populations could theoretically mask the overall effect of phytase on manure-P inputs from poultry. Because manure transport can also affect local manure-P inputs, expected reductions cannot be attributed solely to poultry phytase implementation in this dataset. However, the greatest expected reductions in manure-P inputs tend to occur in those HUC8s containing the largest poultry populations (fig. 12).

The most notable exception to this pattern is the Sinnemahoning HUC8. Results from the Scenario Builder model indicated that manure-P inputs in the Sinnemahoning increased almost hundredfold, even with BMP implementation, between 1985 and 2012. However, based on data from LaMotte (2015), this analysis indicated that the Sinnemahoning ranked among the lowest for poultry inventories among all HUC8s in the watershed in 2012. Between 2007 and 2012, its poultry inventory declined from 2,483 to 1,792 individuals, and livestock populations also remained low. This anomaly was caused by a protocol used by the CBP to account for poultry populations that were reported only at the state level in the USDA COA due to privacy restrictions. The LaMotte (2015) dataset included only those animals that were reported at the county scale, whereas the CBP used an algorithm to allocate poultry reported at the state level to local areas around the watershed. As a result, the CBP

${ }^{8}$ The Potomac and Virginia Western Shore.
Phase 5.3.2 Scenario Builder dataset assumed a large allocation of poultry to Cameron County, Pennsylvania (thus to the Sinnemahoning HUC8), whereas LaMotte (2015) did not.

\section{Land-Use Change Best Management Practices (BMPs)}

Between 1985 and 2012, reported implementation of agricultural land-use change BMPs increased from 60 to about 651,000 acres per year across the watershed, for an accumulated total of almost 4.5 million acres in 2012. However, 85 percent of the cumulative increase occurred during the last 6 years of the period, from 2006 to 2012 (fig. 13). Although major jurisdictions have reported BMP implementation to the CBP since the late 1990s, the establishment of the Chesapeake Bay TMDL in 2010 provided incentive to improve BMP reporting. At that time, jurisdictions were permitted to update past reporting of BMP implementation as far back as 2006 (Chesapeake Bay Program Watershed Technical Work Group, 2013). In recent years, the CBP has developed new tools to improve the counting and reporting of BMP implementation, however, verification of historical BMP implementation records remains challenging (National Research Council, 2011). It is likely that the increase in implementation observed in recent years is at least partially a consequence of increased reporting rather than increased implementation.

The vast majority of land-use change BMP acreage was located in the regions including the most agricultural acreage (the Susquehanna, Potomac, and Eastern Shore regions). However, when implementation was adjusted to account for the amount of eligible ${ }^{9}$ acreage in each HUC8, the resulting measure of implementation intensity of land-use change BMPs (such as implementation per acre of eligible land) in the agricultural sector varied both within and among regions, from as low as 2.6 percent in the Chenango HUC8 to as much as 32 percent in the Sinnemahoning HUC8 (fig. 14), and did not necessarily occur in those HUC8s with the most agricultural activity. For example, the lower part of the Susquehanna region and the central part of the Potomac region have relatively high agricultural $\mathrm{N}$ - and $\mathrm{P}$-input intensities (see figure 8), but show some of the lowest agricultural land-use change BMP implementation intensities (percent of eligible acres).

\footnotetext{
${ }^{9}$ Acres determined to be appropriate for implementation of agricultural land-use change BMPs.
} 
Table 14. Dairy precision feeding implementation rates in the Chesapeake Bay watershed, 2007-12 (Devereux and others, 2017).

[BMP, best management practice]

\begin{tabular}{llcrrr}
\hline Year & BMP & Region & $\begin{array}{c}\text { Amount } \\
\text { implemented } \\
\text { (animal units) }\end{array}$ & $\begin{array}{c}\text { Animal } \\
\text { units } \\
\text { available }\end{array}$ & $\begin{array}{c}\text { Percent } \\
\text { implementation }\end{array}$ \\
\hline 2007 & Dairy precision feeding; forage management & Susquehanna & 352 & 29,166 & 1 \\
\hline 2008 & Dairy precision feeding; forage management & Susquehanna & 3,634 & 39,186 & 9 \\
\hline 2009 & Dairy precision feeding; forage management & Susquehanna & 6,724 & 38,589 & 17 \\
\hline 2010 & Dairy precision feeding; forage management & Susquehanna & 1,710 & 72,043 & 2 \\
\hline 2011 & Dairy precision feeding; forage management & Susquehanna & 3,199 & 31,351 & 10 \\
\hline 2012 & Dairy precision feeding; forage management & Susquehanna & 5,541 & 514,766 & 1 \\
\hline 2012 & Dairy precision feeding; forage management & Potomac & 98 & 69,645 \\
\hline
\end{tabular}

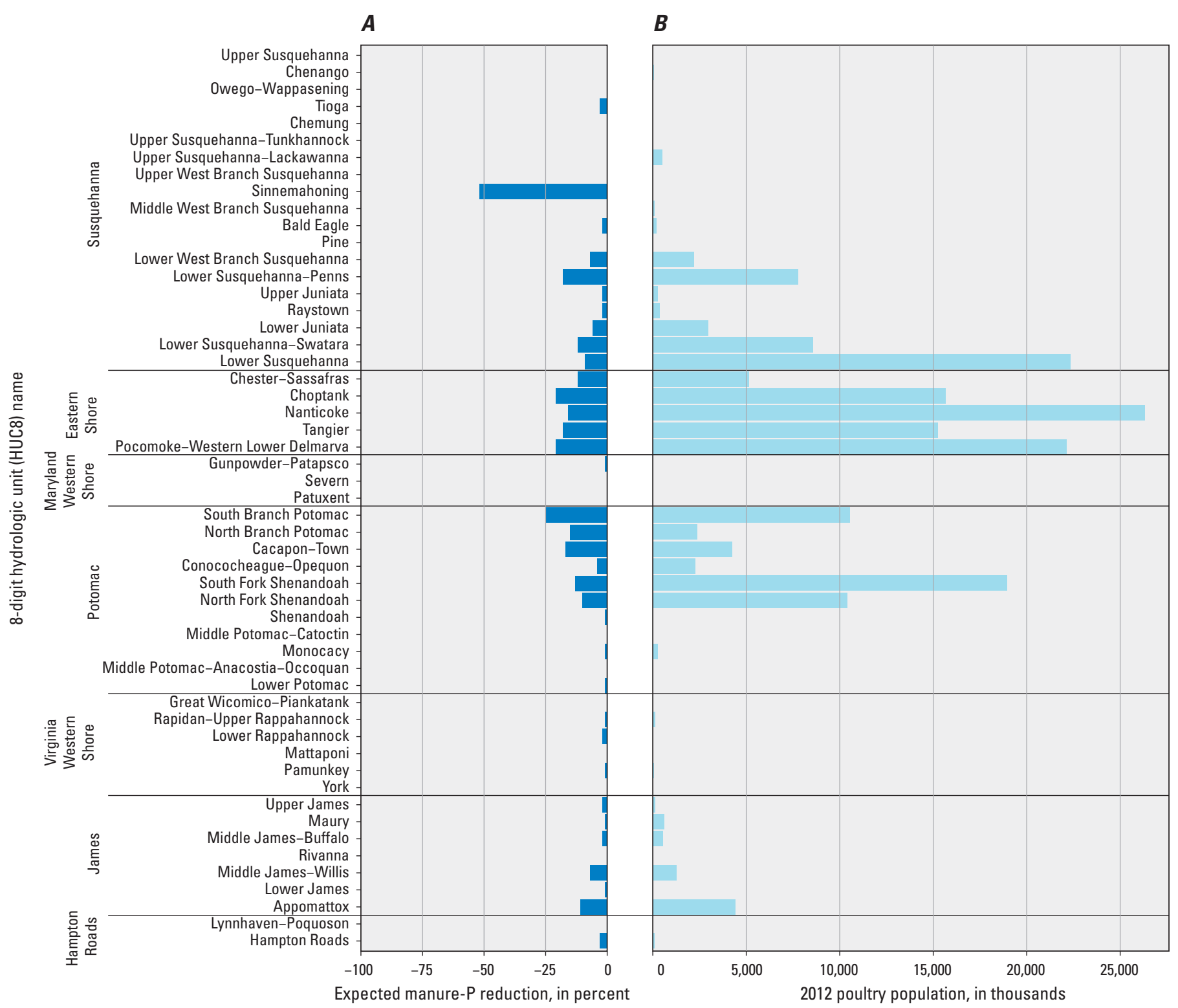

Figure 12. A, expected percent change in manure-phosphorus (manure-P) applications due to best management practices (BMPs) from 1985 to 2012 (dark blue bars), and B, 2012 poultry populations (light blue bars) in the Chesapeake Bay watershed. [In general, BMP effects on manure-P inputs were expected only in basins where poultry populations were located. Exceptions were the Tioga, Upper Susquehanna-Lackawanna, and Sinnemahoning Basins.] 


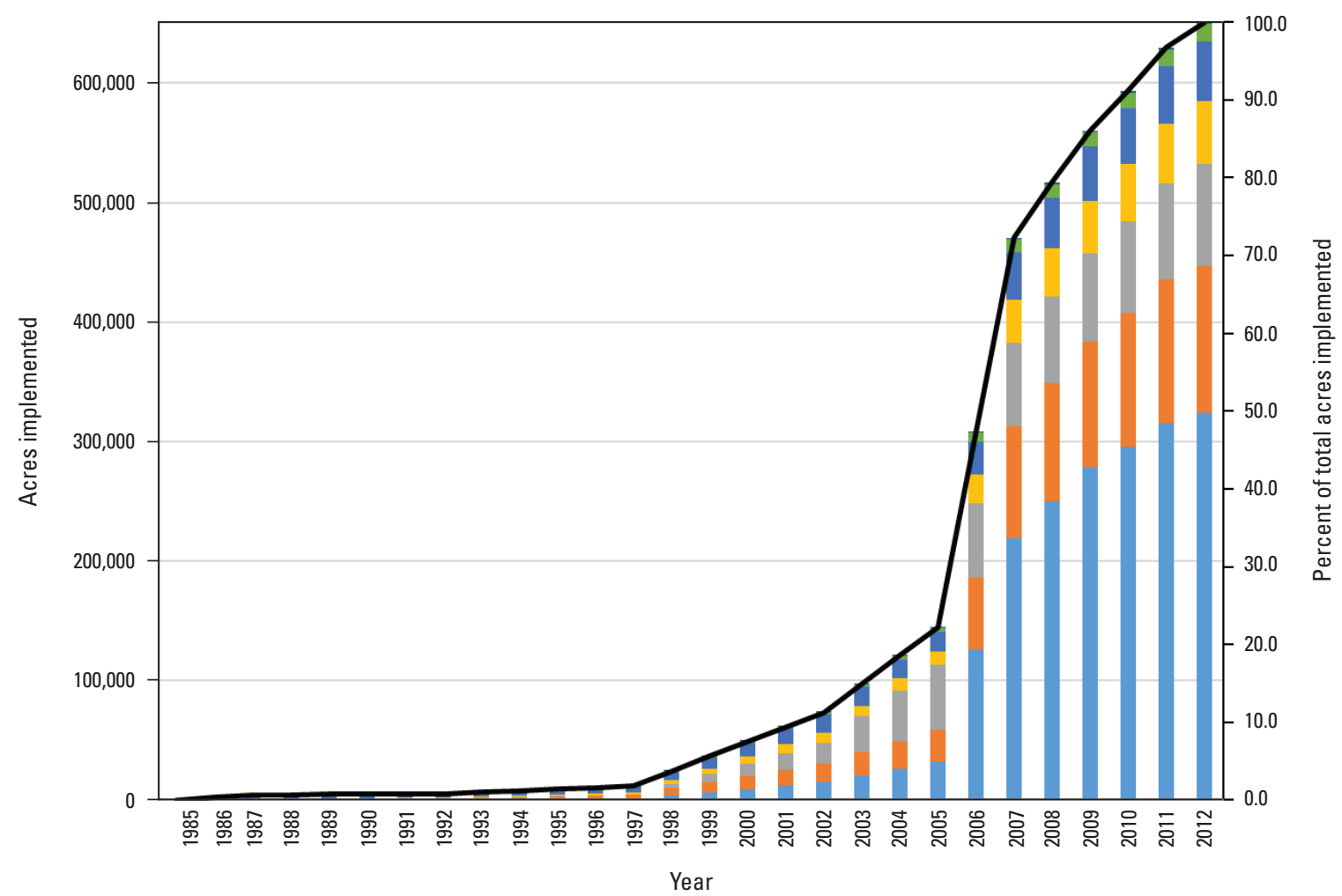

EXPLANATION

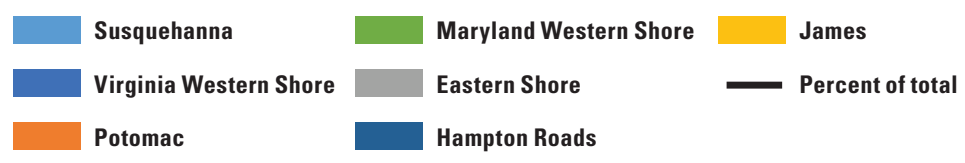

Figure 13. Reported implementation of agricultural land-use change best management practices (BMPs) for major regions of the Chesapeake Bay watershed, 1985-2012. [Bars represent annual implementation; black line represents the cumulative total of BMP acreage for all regions.] 


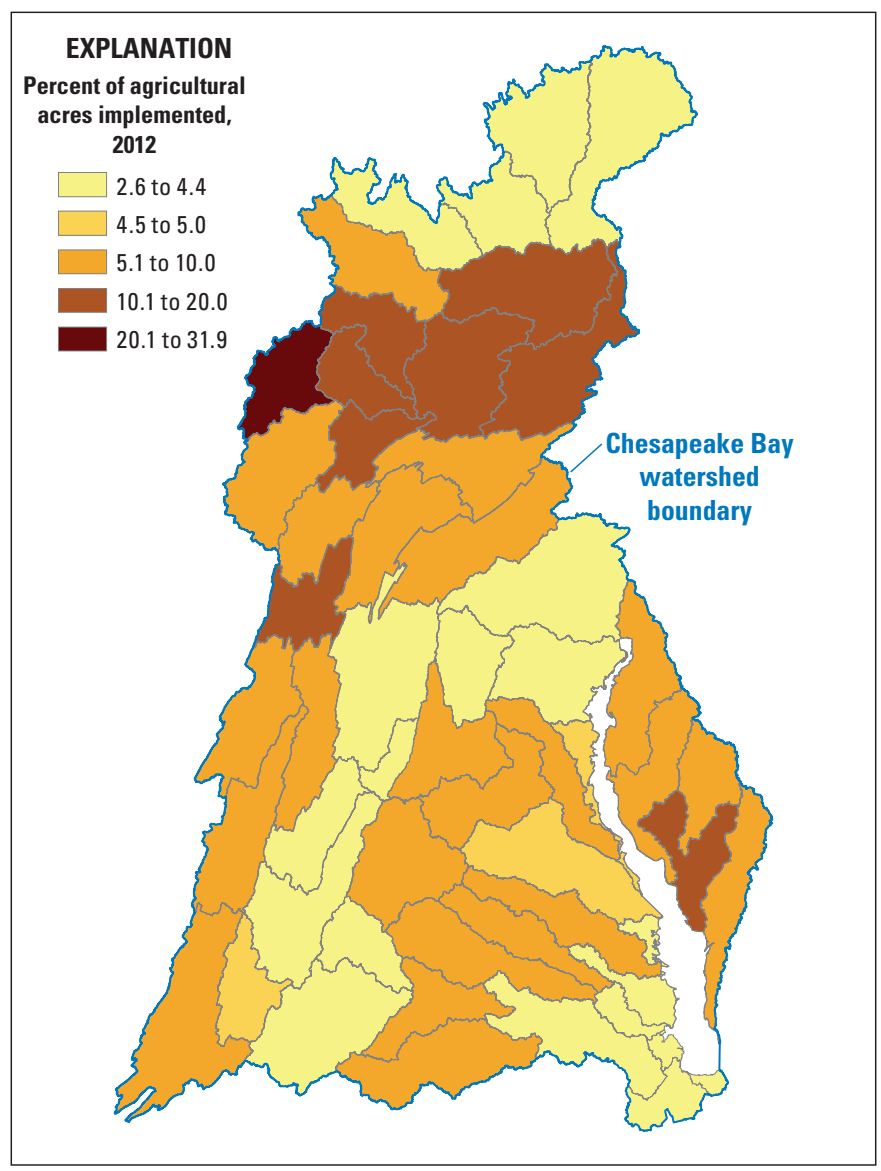

Figure 14. Implementation of agricultural land-use change best management practices (BMPs) as of 2012 (percent of eligible acres) in the Chesapeake Bay watershed.

\section{Summary}

The U.S. Geological Survey (USGS) serves as an integral part of the effort to advance the understanding of factors affecting aquatic conditions in the Chesapeake Bay watershed and estuary. Understanding temporal and spatial patterns in manure and fertilizer inputs, as well as in associated agricultural practices, enables further interpretation of the results of research on changes in riverine and estuarine aquatic conditions. To that end, this report evaluates the magnitude and spatial variability of nitrogen $(\mathrm{N})$ and phosphorus $(\mathrm{P})$ inputs from manure and fertilizer from 1950 through 2012 at three spatial scales: the entire Chesapeake Bay watershed, 7 regions within the watershed, and the 53 8-digit hydrologic units (HUC8s) that are contained within the watershed. Changes over time in natural, developed, and agricultural land use were also characterized, as were temporal and spatial variability in agricultural land-use practices such as livestock and poultry populations, and the cultivation of different crop types. Relations between land-use change, agricultural practices, and manure and fertilizer inputs were explored. In addition, data on the reported implementation of land-use change and animal best management practices (BMPs) from 1985-2012 were used to describe temporal and spatial patterns in BMP implementation intensity, and modeling scenarios from the Chesapeake Bay Program (CBP) Scenario Builder were used to estimate the expected effect of these BMPs on manure and fertilizer inputs across the watershed.

Inputs of $\mathrm{N}$ and $\mathrm{P}$ to the watershed from manure increased moderately and steadily between 1950 and 2012, reflecting a small increase in animal inventory as measured in Animal Units (AUs), but with a shift from cows to poultry. Fertilizer-N inputs increased dramatically but experienced large inter-annual variability, whereas inputs of fertilizer-P decreased slightly. Patterns were more varied at the HUC8 scale, particularly in the latter part of the data record. Fertilizer inputs decreased in most areas throughout the Bay watershed from 1982-2012, whereas manure input increased in almost half of the HUC8s studied. Manure inputs also were re-distributed, most notably from the northern to the southern Susquehanna region, and from the central to the western part of the Potomac region. These patterns were consistent with changes in farming practices. Decreases in pasture and cropland were 
accompanied by reduced agricultural nutrient inputs per acre of farmland in some areas, whereas other areas experienced an increase in the intensity of agricultural practices even as the actual amount of land in farms declined. Greater intensity of $\mathrm{N}$ inputs tended to occur in row-crop-dominated regions and in areas that saw large increases in poultry populations, whereas $\mathrm{N}$-input intensity was lower and was more likely to decline over time in regions dominated by forage crops and cows. Nutrient input patterns in predominantly urban HUC8s deviated from those in predominantly agricultural HUC8s.

Exploratory analysis of this dataset identified a positive correlation between fertilizer-N use and the proportion of acres planted in grain corn. The proportion of acres planted in silage corn did not exhibit this pattern. Corn silage is usually produced in close proximity to cow populations, possibly increasing the usage of manure rather than fertilizer for meeting crop $\mathrm{N}$ requirements. These findings can be used to evaluate whether increased cultivation of corn, which often has greater $\mathrm{N}$ requirements than other crops, results in larger fertilizer-N inputs.

Finally, the reported implementation of BMPs that affect agricultural nutrient inputs was expected to reduce $\mathrm{N}$ inputs by less than 1 percent, and $\mathrm{P}$ inputs by just over 5 percent, across the watershed. The greater influence on $\mathrm{P}$ inputs, due almost entirely to reduced manure-P inputs, was concentrated in areas with high poultry populations, and most likely resulted from the addition of the phytase enzyme to poultry feed. Reported implementation of agricultural land-use change BMPs increased substantially after 2005 , but this may have been at least partially due to improved mechanisms for BMP reporting rather than solely due to increased implementation on the ground. Implementation of land-use change BMPs also varied geographically, ranging from less than 3 percent to just over 30 percent of eligible acres. The intensity of land-use change BMP implementation was not consistently aligned with areas experiencing the greatest intensity of manure and fertilizer nutrient inputs.

\section{References Cited}

American Society of Agricultural and Biological Engineers, 2005, Standard D384.2, Manure production and characteristics: American Society of Agricultural and Biological Engineers (ASABE) Standards publication ASAE D384.2, accessed November 16, 2016, at https://elibrary.asabe.org/ abstract.asp? aid $=32018$.

Ator, S.W., Brakebill, J.W., and Blomquist, J.D., 2011, Sources, fate, and transport of nitrogen and phosphorus in the Chesapeake Bay watershed: An empirical model: U.S. Geological Survey Scientific Investigations Report 2011-5167, 27 p., accessed August 17, 2017, at https://pubs. usgs.gov/sir/2011/5167/.
Ator, S.W., and Garcia, A.M., 2016, Application of SPARROW modeling to understanding contaminant fate and transport from uplands to streams: Journal of the American Water Resources Association (JAWRA), v. 52, no. 3, p. 685-704, doi/10.1111/1752-1688.12419, accessed August 17, 2017, at http://onlinelibrary.wiley.com/ doi/10.1111/1752-1688.12419/full.

Basden, T.J., Abaye, A.O., and Taylor, R.W., 2006, Crop production, chap. 5 in Haering, K.C., and. Evanylo, G.K., eds., The Mid-Atlantic nutrient management handbook: Mid-Atlantic Regional Water Program Publication 06-02, accessed September 2, 2016, at http://extension.umd. edu/sites/extension.umd.edu/files/_docs/programs/anmp/ MANMH_complete.pdf.

Beegle, D., 2013, Nutrient management and the Chesapeake Bay: Journal of Contemporary Water Research and Education, v. 151, no. 1, p. 3-8, DOI: 10.1111/j.1936704X.2013.03146.x, accessed August 17, 2017, at http://onlinelibrary.wiley.com/doi/10.1111/j.1936704X.2013.03146.x/full.

Boesch, D.F., Brinsfield, R.B., and Magnien, R.E., 2001, Chesapeake Bay eutrophication: scientific understanding, ecosystem restoration, and challenges for agriculture: Journal of Environmental Quality, v. 30, no. 2, p. 303-320, doi:10.2134/jeq2001.302303x, accessed August 17, 2017, at https://dl.sciencesocieties.org/publications/jeq/ abstracts/30/2/303.

Chesapeake Bay Program, 2013, Estimates of county-level nitrogen and phosphorus data for use in modeling pollutant reduction, documentation for Scenario Builder version 2.4, accessed August 17, 2017, at https://www.chesapeakebay. net/documents/SB_Documentation_V24_01_04_2013.pdf.

Chesapeake Bay Program, 2015, Recommendations to estimate poultry nutrient production in the Phase 6 Watershed Model: Report of the Agricultural Modeling Subcommittee to the Poultry Litter Subcommittee and Agriculture Workgroup, March, 2015, accessed August 17, 2017, at http://www.chesapeakebay.net/channel_files/22429/recommendations_to_estimate_poultry_nutrients_for_phase_6_ model_03062015.pdf.

Chesapeake Bay Program Watershed Technical Workgroup, 2013, Minutes of the Chesapeake Bay Program Watershed Technical Workgroup (WTWG) Conference Call, July 8, 2013, accessed August 17, 2017, at https://www.chesapeakebay.net/channel_files/19141/wtwg_070813_minutes_ final_draft.pdf.

Devereux, O.H., Keisman, J.L., LaMotte, A.E., and Sekellick, A.J., 2017, Animal Best Management Practice by Chesapeake Bay Watershed Region From 1985 to 2014: U.S. Geological Survey data release, https://doi.org/10.5066/ F79P30JM. 
Falcone, J.A., 2015, U.S. conterminous wall-to-wall anthropogenic land-use trends (NWALT), 1974-2012: U.S. Geological Survey Data Series 948, 33 p. plus appendixes 3-6 as separate files, accessed August 17, 2017, at http://dx.doi. org/10.3133/ds948.

Kellogg, R.L., Lander, C.H., Moffitt, D.C., and Gollehon, N., 2000, Manure nutrients relative to the capacity of cropland and pastureland to assimilate nutrients: spatial and temporal trends for the United States: United States Department of Agriculture publication number nps00-0579, accessed August 17, 2017, at https://www.nrcs.usda.gov/wps/portal/ $\mathrm{nrcs} /$ detail/national/technical/nra/?cid=nrcs143_014126.

Kemp, W.M., Boynton, W.R., Adolf, J.E., Boesch, D.F., Boicourt, W.C., Brush, G., Cornwell, J.C., Fisher, T.R., Glibert, P.M., Hagy, J.D., Harding, L.W., Houde, E.D., Kimmel, D.G., Miller, W.D., Newell, R.I.E., Roman, M.R., Smith, E.M., and Stevenson, J.C., 2005, Eutrophication of Chesapeake Bay: historical trends and ecological interactions: Marine Ecology Progress Series, v. 303, p. 1-29, accessed August 17, 2017, at http://www.int-res.com/articles/feature/m303p001.pdf.

LaMotte, A.E., 2015, Selected items from the Census of Agriculture at the county level for the conterminous United States, 1950-2012: U.S. Geological Survey data release, http://dx.doi.org/10.5066/F7H13016.

Linker, L.C., Batiuk, R.A., Shenk, G.W., and Cerco, C.F., 2013, Development of the Chesapeake Bay watershed Total Maximum Daily Load Allocation: Journal of the American Water Resources Association (JAWRA), v. 49, no. 5, p. 986-1,006, DOI 10.1111/jawr.12105, accessed August 17, 2017, at http://onlinelibrary.wiley.com/ doi/10.1111/jawr.12105/full.

MacDonald, J.M., Ribaudo, M.O., Livingston, M.J., Beckman, J., and Huang, W., 2009, Manure use for fertilizer and for energy: Report to Congress: United States Department of Agriculture, Economic Research Service, Administrative Publication No. (AP-037), 53 pp, accessed September 2, 2017, at https://www.ers.usda.gov/publications/pubdetails/?pubid $=42740$.

National Research Council, 2011, Achieving nutrient and sediment reduction goals in the Chesapeake Bay: An evaluation of program strategies and implementation: Washington, D.C., National Research Council, National Academy of Sciences, 258 p., accessed April 27, 2015, at https://www. chesapeakebay.net/channel_files/21727/2011_nas_report. pdf.
R Core Team, 2016, R: A language and environment for statistical computing: Vienna, Austria, R Foundation for Statistical Computing, https://www.R-project.org/.

Ribaudo, M.O., Gollehon, N.R., and Agapoff, J., 2003, Land application of manure by animal feeding operations: Is more land needed?: Journal of Soil and Water Conservation, v. 58, no. 1, p 30-38, accessed May 14, 2018, at http:// www.jswconline.org/content/58/1/30.abstract.

Sekellick, A.J., 2017, Nitrogen and phosphorus from fertilizer and manure in the Chesapeake Bay watershed, 1950-2012: U.S. Geological Survey data release, http://doi.org/10.5066/ F7TQ6011.

Stuart, D., Basso, B., Marquart-Pyatt, S., Reimer, A., Robertson, G.P., and Zhao, J., 2015, The need for a coupled human and natural systems understanding of agricultural nitrogen loss: Bioscience, v. 65, no. 6, p. 571-578, accessed August 17, 2017, at https://doi.org/10.1093/biosci/biv049.

U.S. Department of Agriculture, 2014, 2012 Census of Agriculture: United States summary and state data, Volume 1, Geographic Area Series, Part 51: United States Department of Agriculture National Agricultural Statistics Service (NASS), May 2014, Report AC-12-A-51, accessed May 9, 2017, at https://www.agcensus.usda.gov/Publications/2012/ Full_Report/Volume_1,_Chapter_1_US/usv1.pdf.

U.S. Environmental Protection Agency, 2010, Chesapeake Bay Total Maximum Daily Load for nitrogen, phosphorus and sediment: Annapolis, Maryland, U.S. Environmental Protection Agency Chesapeake Bay Program Office, accessed August 17, 2017, at https://www.epa.gov/chesapeake-baytmdl/chesapeake-bay-tmdl-document.

U.S. Geological Survey and U.S. Department of Agriculture, Natural Resources Conservation Service, 2013, Federal Standards and Procedures for the National Watershed Boundary Dataset (WBD) (4th ed.): Techniques and Methods 11-A3, 63 p., accessed August 17, 2017, at http://pubs. usgs.gov/tm/11/a3/. 


\section{Appendix 1}

Inputs of nitrogen $(\mathrm{N})$ to the Chesapeake Bay watershed's 53 8-digit hydrologic units (HUC8s) from manure, fertilizer, and the two sources combined. Inputs, as well as changes in those inputs, between the decades 1992-2002 and 2002-12 are provided. 


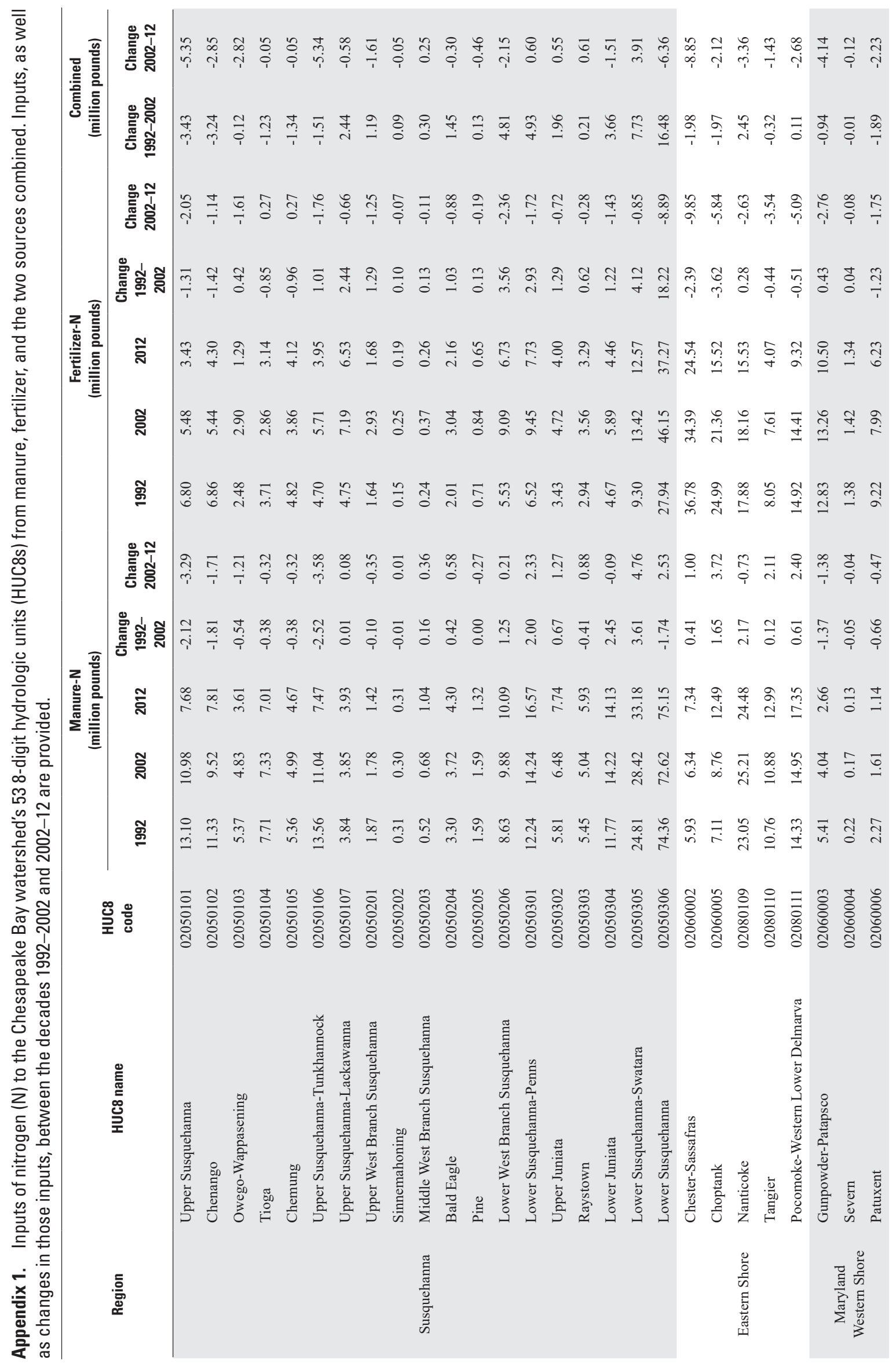




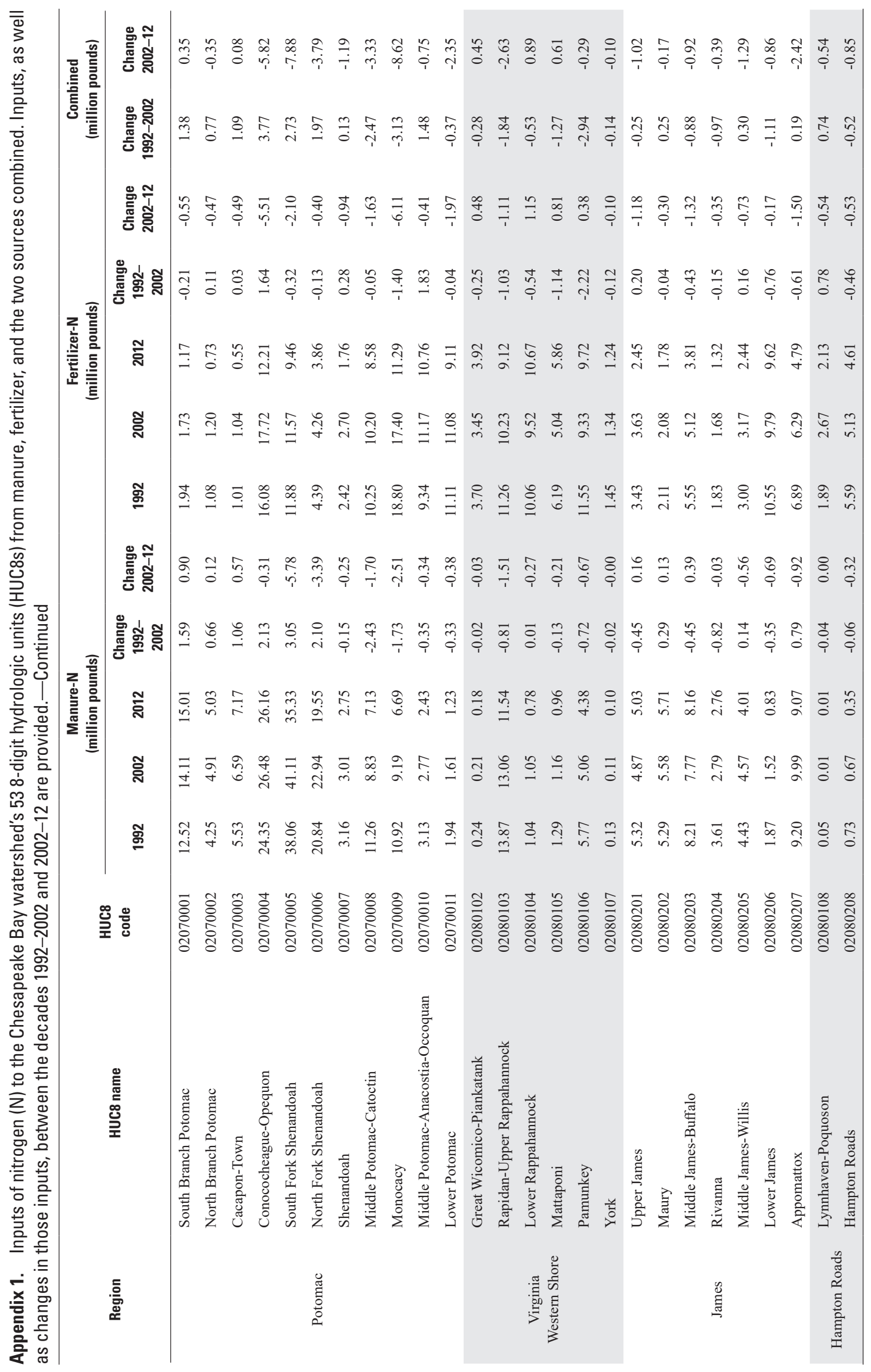




\section{Appendix 2}

Inputs of phosphorus (P) to the Chesapeake Bay watershed's 53 8-digit hydrologic units (HUC8s) from manure, fertilizer, and the two sources combined. Inputs, as well as changes in those inputs, between the decades 1992-2002 and 2002-12 are provided. 


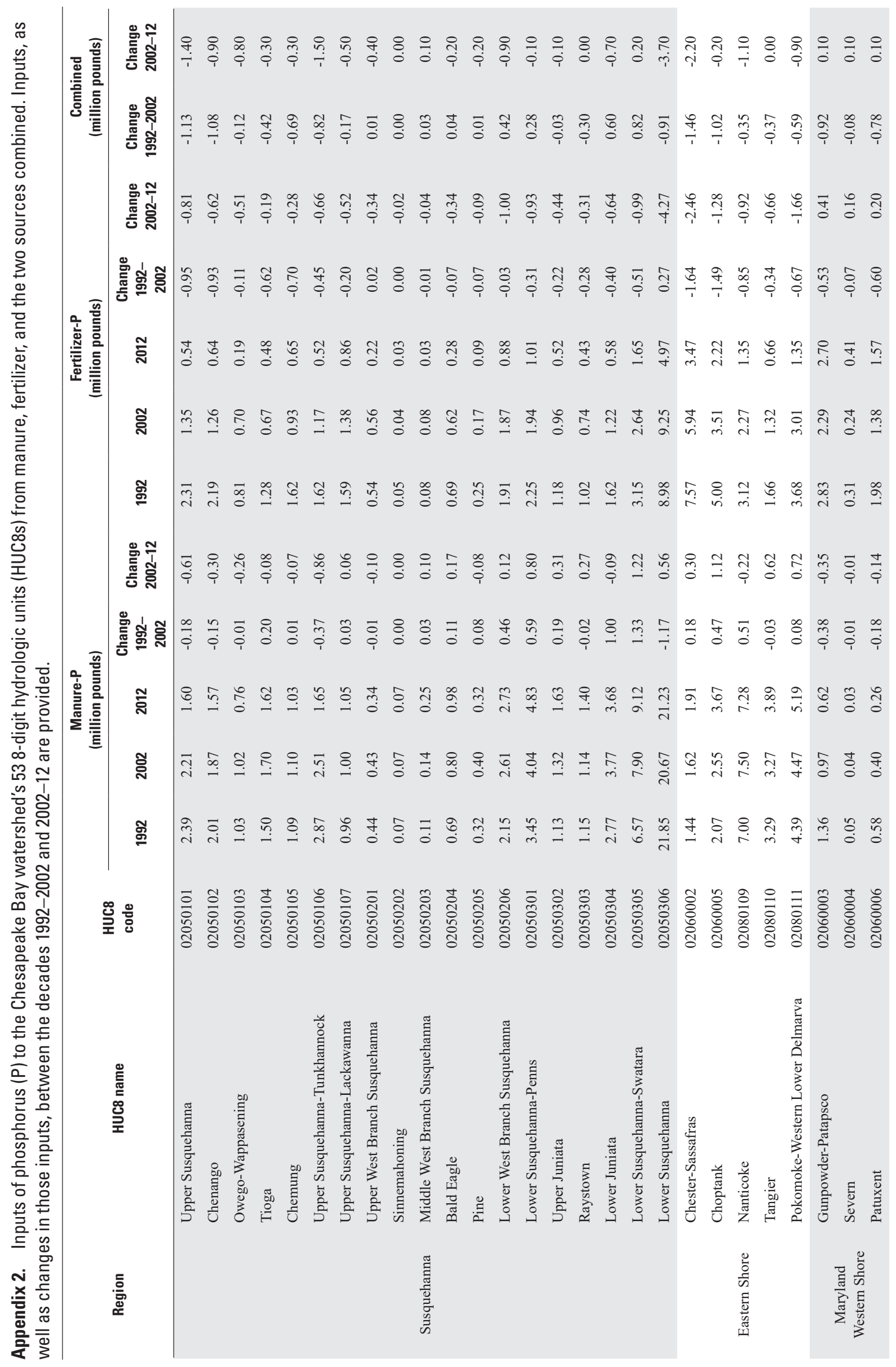




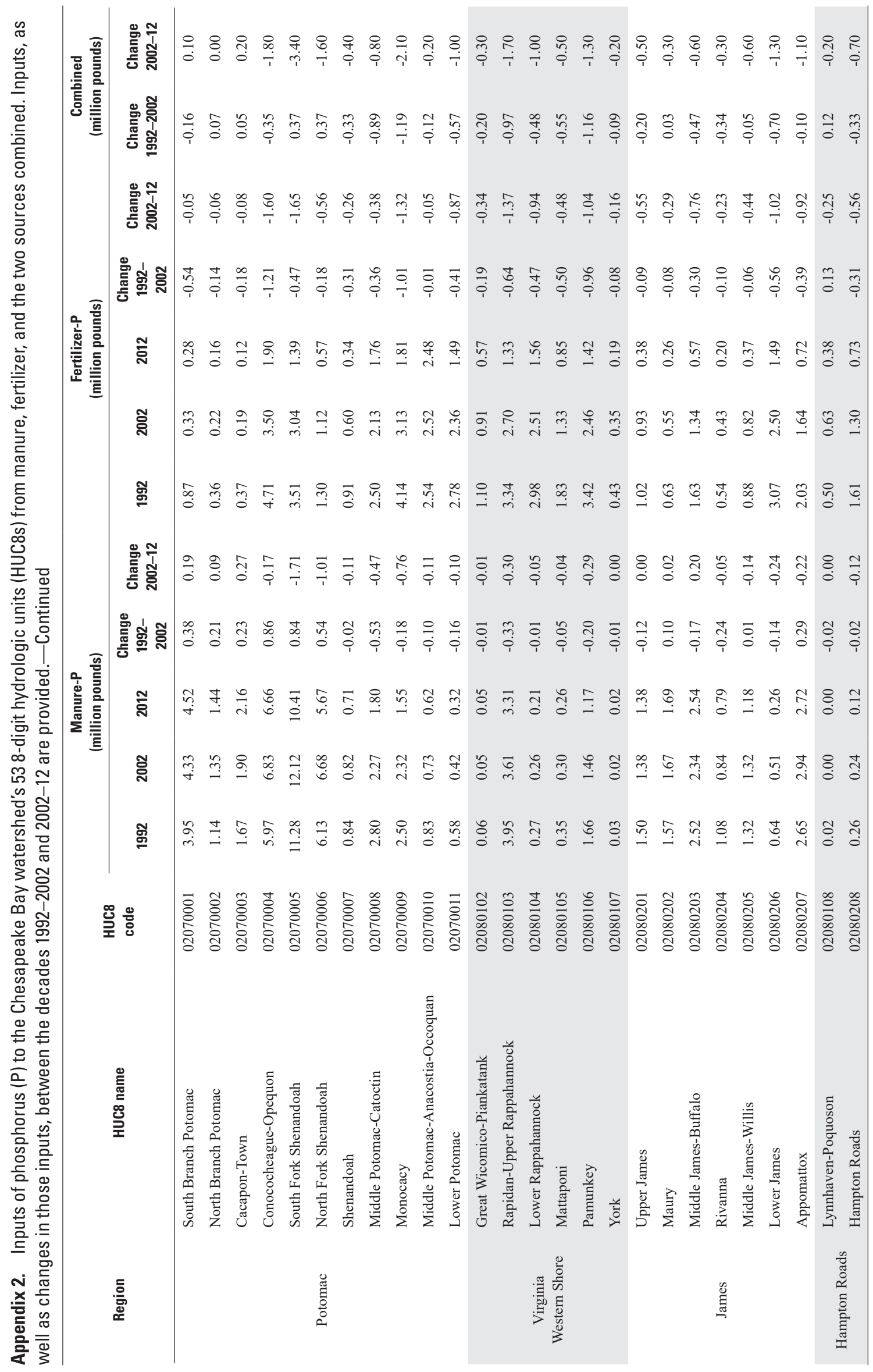


For additional information, contact:

Director, MD-DE-DC Water Science Center

U.S. Geological Survey

5522 Research Park Drive

Baltimore, MD 21228

or visit our website at: http://md.water.usgs.gov/

Publishing support provided by West Trenton Publishing Service Center 
